\title{
Terepmunka, módszertan és antropológiai muzeológia
}

DOI: $\underline{10.54742 / \text { tabula.2019.1-2.02 }}$

1.

A terepkutatás mint megfigyelési technika az antropológiai módszertannak máig szerves, meghatározó és alapvető része. Ennek ellenére a vele kapcsolatos kérdések és problémák jelentős része csak az utóbbi évtizedekben került előtérbe (lásd Rabinow 1977, 2006; Gupta - Ferguson 1997; Lassiter 2004). Ezekből kiindulva megpróbálom belehelyezni a terepmunkát az antropológia, a néprajz és a múzeum, illetve a résztvevő megfigyelés, az antropológiai tárgykutatás és a tárgygyüjtés viszonyrendszerébe. Részben a tárgyak antropológiai szerepének térnyerése, részben a terepmunkával kapcsolatban (is) újabban felmerülő néhány kritikai gondolat indokolja a tágabb kontextus keresése.

2.

A tanulmány két résztémát igyekszik körüljárni. Megnézi, hogyan értelmezhető ma általában a terep és a terepmunka, tudunk-e ezzel kapcsolatban újat mondani. Itt érdemes a legtágabb értelemben vett terepből kiindulni, mely a nem társadalomtudományi célú vizsgálatokat is magában foglalja. Ebben a megközelítésben válik azután érdekessé, mennyiben más az antropológiai (illetve általában a társadalomtudományi) jellegű terepmunka. Itt nyilvánvalóan a megértés és a részvétel (kommunikáció) kerül a középpontba. Végül a múzeumi jellegü antropológiai terep lehetőségei és sajátosságai lépnek az előtérbe. Ezzel kapcsolatban a két fő kérdés a gyưjtés és a terep kapcsolata, valamint a múzeum (a gyüjtemény) mint terep jellege.

3.

A terepkutatást a tudományos megismerés egy olyan sajátos formájának lehet tekinteni, mely a helyszínre mint környezetre (lokalitásra), az ott megélt tapasztalatra és annak nyitottságára (a felfedezésre és a feltérképezésre) helyezi a hangsúlyt. A résztvevő megfigyelés ezen belül az ismeretszerzés egy közvetlen módjaként jelenik meg, mely személyes és aktív, a megfigyelendő személyekkel való együttmüködésen alapul.

A terep általános formájában valamennyi olyan empirikus tudomány vagy megismerési mód, tevékenység elengedhetetlen részét alkotja, mely egy addig ismeretlen vagy valamilyen tekintetben feltárásra szoruló környezetre összpontosít. Ebben az értelemben minden helyszíni megfigyelés és gyưjtés, mely természettudományos érdeklődésű, szintén a terepen zajlik. Ez a megfigyelési technika például a geológia egyik gyakori eszköze, de a biológiai viselkedésközpontú megfigyelések esetében is az egyik alapvető ismeretszerzési technika. Állatok társas viselkedésének tanulmányozása tekintetében például fontos, hogy a kutatók természetes körülmények között is vizsgálhassák az állatok viselkedését, társas kapcsolatait. Itt már kezd kirajzolódni, hogy e módszer egyik problémája a megfigyelés és a részvétel kérdésekkel teli viszonya, vagyis az, hogyan hat a kiindulópontra, a saját, természetes környezetre magának a megfigyelőnek a jelenléte. Mennyire és mennyi- 
ben változtat, módosít ezen? Ezzel elérkezünk az antropológiai terep problémájához: a megfigyeléskor, mely itt óhatatlanul megköveteli a részvételt, mi történik az antropológus és a vizsgált személyek, csoportok között. Ebből kiindulva, mik a feltételei a résztvevő megfigyelésnek mint megértésnek?

Az antropológiai „terep” ebben az értelemben tehát a társadalmi, kulturális megismerésnek, a társadalmi és kulturális jelenségek múködésének a helyszíne, kerete, megnyilvánulása, folyamata. Egyfajta nyitott környezet, mely számtalan kérdést, választ, értelmezést, leírást enged meg, illetve zár ki. A terepet ebben az értelemben kiválasztjuk, nem pedig létrehozzuk, mivel a terep éppen ebben a többletében, adott voltában fontos. A terep mint helyszín ugyanakkor számtalan formában és mélységben jelenhet meg a kutató számára. Az antropológus részt vehet a publikus vagy privát terekben, eseményeken, többé vagy kevésbé irányíthatja az eseményeket, ráláthat vagy sem bizonyos dolgokra. Mindegyik esettípus egyben a kutatás és a gyüjtés kontextusa, így fontos az értelmezéshez.

Ezt a terepet akarjuk tehát kutatóként megérteni és leírni a maga működésében, folyamatában és változásában, ugyanakkor minden esetben valamilyen nézőpontból, amely akár szintén változhat is a későbbiekben. A klassszikus terepmunka problematizálására jellemző tehát az etnográfiai szöveg, a kutató és a kutatott viszonya, valamint a világ változása (Gupta - Ferguson 1997:3)

A terep az antropológia szempontjából maga a „világ”, amelyet értelmezni, megérteni szándékozik. Ily módon a terepmunka fogalmilag is elválaszthatatlan tőle. Az antropológia klasszikus értelemben ugyanis eleve más világok, életmódok feltérképezésére és megértésére törekszik, és ehhez szükség van e világok elérésére. Az más kérdés, milyen jellegü és mértékủ hozzáférése van a terephez, illetve milyen hozzáférést választ, részesít előnyben adott célból vagy időszakban. Az antropológia korai korszakában a terepról való közvetett ismeretek legalább annyira fontosak voltak, mint a közvetlenek, a modern antropológia azonban már a tereppel való közvetlen kapcsolatból indul ki.

8.

A terep ugyanakkor a maga részéról számos egyéb ismeretszerzési módot képes támogatni, elősegíteni vagy megengedni (lásd például az interjút, kísérletet), a résztvevő megfigyelésnek viszont a feltétele és alapja a terep. A terep a maga öszszetettségében egyszerre nyitott és korlátozó (lásd Gupta - Ferguson 1997), demokratikus és autoriter, egyéni és kollaboratív. Adott kérdésekkel, modellekkel kapcsolatban kérdezhető meg, illetve adott kérdésekkel kapcsolatban választható ki.

9.

A terepmunka sajátossága (amivel mást, többet tud adni egyéb kutatási technikáknál) általános értelemben a társadalmi jelenségek, folyamatok sajátos, „tipikus”, közvetlen, természetes környezetben való múködésének megfigyelése (lásd Forster 2012:184), ezen belül a rendszeresen előforduló jelenségeknek, ezek összefüggéseinek, a viselkedéseknek, illetve az ettől eltérő folyamatoknak a megismerése. Ezek tisztázása azért fontos, mert a terepmunka fogalmi készlete a mai napig nem igazán részletes és kidolgozott (Rees 2007; Rabinow 1977, 2006). Nehéz ugyanis megmondani, hogy akkor, amikor benne vagyunk a terepmunkában, mi is történik (pontosan). 
10.

A terep jobb fogalmi megragadása érdekében lehet ugyan hangsúlyozni az egyes kulturális-társadalmi jelenségeknek kontextusba helyezését mint a terepkutatás célját, ám ez alaposabban megnézve túl erős követelménynek látszik. A terep ugyan a környezet megértését célozza meg, de ennek szerepe sokkal változatosabb, mint pusztán a kontextusban való értelmezés. Bizonyos esetekben ez ugyanis csak kiemelést tartalmaz, például még ismeretlen fauna, flóra, nép megtalálása, máskor valóban az a kérdés, hogy a megfigyelt dolog, jelenség hogyan illeszkedik bele a szúkebb vagy a tágabb környezetébe (azaz a jelenségek milyen kapcsolatban állnak egymással).

11.

A terepkutatás során gyakran éppen a feltérképezésen van a hangsúly, vagyis a kiválasztott környezet milyensége az érdekes, adott szempontból. A terepmunka sok esetben témákat keres, olyan jelenségeket, melyeket érdemes megmagyarázni vagy értelmezni. A terep ilyen értelemben tehát az idegen, a még ismeretlen keresése is, az otthontól, az ismerttől eltérő, távoli helyszín megismerése, mely éppen a megismerés során válik otthonosabbá. A „terep” a Másik helyszíne, ugyanakkor az otthonosság (az ottani otthonosság elérése) révén kezd múködni (Gupta - Ferguson 1997:13, Latour 1987; Harrison 2013:91).

12.

Az is megfigyelhető, hogy a terep ebben az összefüggésben a közvetlen, adott környezetet jelenti. A tágabb környezet, kontextus ugyanis ennél idóben és térben jóval kiterjedtebb lehet. Amikor például Róheim Géza (1945) álmokat gyưjjtött őslakosoktól Közép-Ausztráliában (1929-ben), akkor olyan csoportokat keresett, melyek tőle (“tőlünk”) a legtávolabb álltak földrajzilag és kulturálisan. Ezek tagjaival ugyan a helyszínen (saját környezetükben) akart találkozni, de ettől a ponttól kezdve valójában az adott téma feltérképezése (összegyưjtése) vált számára fontossá. Ezeket az álmokat tehát nem a helyi társadalmi-kulturális kontextuson belül igyekezett értelmezni, hanem egy jóval tágabb kulturális, pszichoanalitikai kereten belül. Ehhez gyüjtött tehát eseteket, úgy hogy tesztelhesse a tágabb modell érvényességét, általános, egyetemes voltát.

13 .

A terepkutatás a helyszínhez, a környezethez mint forráshoz ragaszkodik, annak kiválasztásához, adott szempontból való bevonásához, kiaknázásához. Látni lehet, hogy ez meglehetősen általános kiindulópont. Minden olyan technikával szemben áll ugyanakkor, mely a helyszín valamilyen mértékű létrehozásával dolgozik, de nem mond semmit sem azzal kapcsolatban, hogyan akarja a kutató kiválasztani és kihasználni magát a helyszínt.

14 .

A terep ebben az értelemben a megismerésnek egy alapvető forrása, melyet adott kutatási megközelítések előnyben részesítenek. Ám az, hogy a terep csupán az ismeretek helyszíne-e vagy éppen az értelmezés témája, a kutatótól függ. Az antropológia korai szakaszában például a terep az adott „típusú” (egzotikus) csoportok tárgyait (vagy történeteit) szolgáltatták, a Malinowski utáni korszakban azonban maga a társadalmi környezet vált a vizsgálat tárgyává. Az is látható azonban, hogy a környezetre vonatkozó ismeretek más jellegü (közvetett) források, technikák révén is hozzáférhetők (valamilyen formában és mélységben), például a tereptől függetlenül lehet ismereteket gyüjteni a terepre (az adott környezetre) vonatkozóan is, mondjuk, interjúk, kérdőívek, beszámolók, filmek, fotók, történetek segítségével. 
15.

A terepkutatás fontos összetevője, hogy adott nézőpontból történik a vizsgálat. A terep megismerése tehát nem azonos az adott csoportba, környezetbe való szocializációval, hanem minden esetben adott kérdések, problémák, kiindulópontok mentén történik, azaz szükségszerüen szelektív és részleges. James Clifford a Writing Culture (Clifford - Marcus eds. 1986) bevezetőjében szintén a „részleges igazságokat” hangsúlyozza az etnográfiai ismeretek esetében. 16.

Bár a kutatandó csoportba szocializáció valamilyen mértékben jelen van minden terepkutatás során (noha ez nem szúkíthető le a társadalmi kapcsolatokra, mivel beletartozik a materiális világ, környezet megismerése is), az adott világ megismerése, megértése csak egyfajta (és nem kizárólagos) alap, háttér, kontextus a kutatói leíráshoz. Ehhez ugyanis meg kell találni a megfelelő leíró nyelvet, valamint ki kell tudni jelölni, mi is az, amit meg akarunk érteni, illetve amit éppen elkezdtünk megérteni, és mihez képest próbáljuk értelmezni.

A terepmunka, és ennek révén a terep mint helyszín mindig viszonylagos az adott társadalmi folyamat és a feltett kérdések, vizsgálandó témák, jelenségek tekintetében. Ha például egy gyưjtő és az általa gyüjtött tárgyak kapcsolata a téma, akkor lehet a gyưjiőnnél való vásárlás a terep. Ha viszont a gyưjiőnnél vásárolt tárgy korábbi használata a kérdés, akkor nyilván nem. A terep maga az a társadalmi, környezeti folyamat, amit a kérdések, problémák kiemelnek, vagy ami a kijelölt dolgokat közvetlenül körülveszi. A terep lehetőségeit (szélsőségeit) a helyszín (terep) és a résztvevő megfigyelés, kérdésfeltevés, valamint a kutató hátterének sokféle 18 (lehetséges) viszonya adja meg.

A terep e szempontok alapján sokkal inkább (sajátosan látott, értelmezett) helyszín, környezet, mint egyszerű kapcsolat a kutató és a kutatott között. Ez utóbbit ugyanis lehetővé tenné a kísérleti, laboratóriumi helyzet is. Éppen ezért a vizsgált praxis közvetlen helyszíne (a megismerés, megértés szándékával) a fontos jellegzetesség. A terep tehát a kutatott társadalmi praxisok (és ezek környezetének) adott helyszínei (social settings), ezeket pedig nem a kutató hozza létre, hanem lehetőségként eleve adottak. Ezekből választ a kutató, ha adott téma, kérdés, probléma érdekli. A kutató és a kutatott közötti kapcsolat természetesen részévé válik a vizsgálat környezetének, hat valamilyen módon és mértékben hat a eseményekre. A terepbe mint helyszínbe való beilleszkedés (az ottlét jellege, módja, ideje, módja, helye) minden bizonnyal fontos tényező a terepmunka eredménye, módja (a hozzáférés mértéke, mélysége) szempontjából. De legalább ilyen fontos mindaz a háttér, amely a kutató kérdéshez kapcsolódik, hiszen ennek mentén viszonyul a terephez a kutató. A terepkutatás ily módon egy adott helyszínhez és problémához való reflexív viszony. Expen ezért önmagában nem tekinthető terepnek egy másik közösségbe való puszta szocializálódás.

19.

Ahhoz, hogy jobban megértsük ezt a helyzetet, Bennett (2013) és a latouri cselekvőhálózatot (actor-network) modellt alkalmazók a ,fieldwork agencement” terminust használják a terepszituáció múködésére és az arra ható erőkre, beleértve az utazást, szállítást, szervezést, a kutatók, gyarmati adminisztrátorok, misszionáriusok stb., valamint a helybeliek tevékenységét, a hang- és képrögzítés technológiáit, a szállás (sátor...) megszervezését, felállítását, a közvetlen vagy közvetett környezetet és az abban való mozgást. Itt központi szerep jut ugyanakkor az ágencia meg- 
osztásának, megoszlásának nemcsak az emberi, hanem a nem emberi aktorok között is. Utóbbi esetében a gyưjjtés technikai eszközeinek is lényeges szerep juthat, mivel hatnak arra, hogy adott „adat” meghatározása esetében mi számít annak, és egyben megszabhatja azt is, hogyan történik a gyüjtés vagy megfigyelés. 20.

A terep általában kétféle formában merül fel a tudományos vizsgálatokban. Részben mint „természetes”, komplex, közvetlen helyszín. Például ilyen a geológiai képződmény, egy pávián horda, egy kórház, egy távoli sziget. Itt az etnográfia, azaz az adott helyszín mint folyamat, jelenség leírása a fontos. Az adott helyszín komplexitásának a megismerése, dokumentálása, az egyediségének valamilyen szintű modellezése az elsődleges cél. Részben azonban a terep (mint résztvevő megfigyelés) nyitott technikaként is múködik, mely ennek révén új szempontokat, jelenségeket képes a figyelem középpontjába állítani. Általában a terepmunkának, illetve a résztvevő megfigyelésnek ott van ma is fontos szerepe, ahol a helyzet a nyitottsága révén túl összetett, és ennek a komplex helyzetnek a feltérképezésére van szükség.

21.

A terep mint nyitott helyszín ellentéte lehet például a laboratórium (kísérlet) mint a kontrollált megfigyelés tere. A terepen sokszor a bizonytalan helyszín váratlan (új) megnyilvánulásait keressük, a laborban a gondosan összeállított szituáció válaszát keressük egy feltett kérdésre. Ha ez igaz, akkor viszont hogyan lehet mégis terepmunkát végezni a laboratóriumban? Hogyan találkozhat e két eltérő technika? Latour és Woolgar (eds. 1986) a laboratórium mint folyamat megértéséhez ugyanis a terepmunkát nélkülözhetetlennek tartják (fieldwork in the lab), Jackson (2013:28) szerint pedig maga a terep egyfajta laboratórium! Nyilvánvalóan vannak tehát nyitottabb és kevésbé nyitott (azaz erősebben és gyengébben kontrollált) helyszínek, ugyanakkor bármely helyszínt lehet zártabb vagy nyitottabb modellekkel feltérképezni, leírni. A laboratóriumi terep esetében a labor mint környezet valójában a laboratóriumi (kontrollált) technikák (tágabb) környezete, helyszíne, világa; ez pedig ugyanolyan nyitott (nem kontrollált) világ, mint a klasszikus terepmunka „természetes” környezete. A terepkutatástól szintén eltérnek ebben az értelemben részben a helyszínt kevésbé figyelembe vevő vizsgálatok (lásd fókuszcsoport, statisztikai felmérés stb.), részben a virtuális modellezések. Vagyis, ha akár az empíria, akár a helyszín gyengül valamilyen tekintetben, kezdünk távolodni a terepkutatástól. A terepmunka tehát a megfigyelő számára fontosnak tartott, adott környezetbeli (inter)akcióik közben vizsgálja a jelenségeket, és ezen belül a nyitott $\mathrm{s}$ a kontrollált helyzet viszonylagos.

22.

A megfigyelés és a kísérlet ugyanakkor egyaránt adatképző tevékenység (Malik 2017:79, 87), mely számos tevékenység, folyamat (manipuláció, beavatkozás, értelmezés) eredményeképpen jön létre (Malik 2017:86). Az ilyen jellegü tudományos aktivitások részei például a leírás, magyarázat, feltételezés, teszt, megfigyelés, mérés, klasszifikálás, reprezentálás, modellezés, szimulálás, szintetizálás, elemzés, absztrahálás, idealizálás (Malik 2017:87).

23.

A terepmunka célja ugyanakkor általában szintén nyitott - ellentétben a laboratóriumi vizsgálatéval. A dokumentációtól az adatgyüjtésen, megértésen, tárgygyüjtésen át a téma, probléma- vagy kérdéskeresésig bármi beleférhet ebbe (lásd Fenske 2007). 
24.

A terep a kontrollált kutatási helyzetekkel ellentétben éppen a helyszín nyitottsága (vagy ahogyan Latour [1986] fogalmaz: bizonytalansága) révén vonzó a tudományos vizsgálatok számára (Austrin -- Farnsworth 2005:161). A kísérlettel ellentétben nem elsősorban jól meghatározott jelenségek válaszai az érdekesek adott kérdésekre, hanem a jelenségek előfordulásának változatai, típusai, kapcsolatai, kontextusai. Bár lehet mondani, hogy a terepkutatás a jelenségeket a „megszokott”, „természetes” környezetükben vizsgálja, ám ez nem feltétlenül igaz minden esetben. Megváltozott vagy folyamatosan változó, új helyzetekben is lehet terepkutatást végezni,. Az igazi különbség inkább abban áll, hogy a nem kontrollált vagy nem a kutató által kontrollált körülmények, helyszínek a meghatározók itt. Ezek ugyanis minden esetben feltárnak valamit (valami újat) az adott jelenség kapcsolatrendszeréből.

25.

A terepmunka által keresett környezetek nagyon sokfélék lehetnek. A klasszikus terepmunka ezek közül néhányat előnyben részesített. Ilyen például a „hagyományos”, „természetes”, „megszokott” kontextusok (lásd Gupta - Ferguson 1997). 26.

Látni lehet tehát, hogy a terep valójában az empíria helyszíne. Ily módon ez az empirikus helyszín mint környezet a legkülönbözőbb szinten és a legkülönbözőbb összefüggéseiben, hálózataiban létezik (a vizsgálat számára). A terepkutatás a jelenségeket a maguk beágyazottságában keresi, konkrét megjelenésükben. Mindezt nevezhetjük lokalitásnak is, ám csak ha figyelembe vesszük, hogy ez nem azonos a térbeli lokalitással, hanem magában foglalja a térben távol múködő viszonyokat is.

Észre lehet venni ebben az összefüggésben, hogy a terep az újabb megosztott (több színterü) terep megközelítések ellenére továbbra is körülhatárolt helyszínként jelenik meg számos módszertani modellben (lásd például Blok 2010: situated globalities; Tsing 2004: global connections). Ez ad ugyanis egyfajta eszköz jelleget a 28. terepmunkának (lásd Candea 2019).

A terep ennek ellenére - térben és időben egyaránt - mobil (tud lenni), változó, mozgó, mozgatható, kiválasztható és bizonyos mértékben módosítható. Olykor szándékosan megváltoztatható (például tárgyak visszavitelével, hangsúlyos részvétellel; vagy akár célzott helyszíni „kísérletekkel”). Minden esetben éppen a terep komplexitása, nyitottsága az, ami lehetővé teszi és indokolja ezt. Manapság a terepmunkára szokás egyfajta térbeli és időbeli keretre, ugyanakkor a közvetlenségen és reflexión át való komplex mozgásra tekinteni (Rees 2007:40; Rabinow 2010:79).

29.

A terep tehát a tapasztalat, a megtapasztalás köré szerveződik. Mindenfajta közvetett információszerzésből hiányzik ez a fajta jellegzetesség. Az ottlét, az adott helyzet komplexitásában való részvétel az elsődleges, azzal a céllal, hogy újfajta megismerés váljon ezáltal lehetővé. Az, hogy ez a megismerés, megtapasztalás azonban milyen, mennyi ismeretet takar, milyen kérdések köré szerveződik, nem fejthető meg a terepmunka jelenségén belül. Azaz ezek a kérdésék másfajta keretben értelmezhetők. Éppen emiatt a terepmunka - egyes kutatók szerint - valójában sokkal inkább technika, nem módszer (Rees 2007:18). De éppen az előzők alapján a módszertan szerves részét képezi. A terepmunka mint technika - ebben az értelemben - szintén nyitott, a terephez hasonlóan. A rövid, hosszú távú, egyszeri 
vagy ismételt, feltérképező vagy módszeres vizsgálat egyaránt beletartozik - akár eltérő célok szolgálatában.

30 .

Kérdés, mennyire feltétel a terepmunka esetében az adott helyzet „természetes” (a kutatástól, kutatótól független) volta. Másként, mennyiben tartoznak a terepkutatás körébe azok a helyzetek, melyek valamilyen mértékben megrendezettek. Mint láttuk, ennek egyik alapformája a kísérlet, a laboratórium. Azt is láttuk, hogy az STS (Science and Technology Studies) terepkutatásai kifejezetten az ilyen jellegü helyzetekre összpontosítottak. Valójában semmi sincs a terepmunka modelljében, mely minősítené a vizsgált helyzeteket. Az egyetlen feltétel, hogy a kutatás közbeni tapasztalat a vizsgált helyzetre, kérdésre és környezetre vonatkozzon. Azaz lehetséges egy fókuszcsoportos vizsgálatot is a terepmunka helyszíneként kezelni, ha az ennek révén szerzett tapasztalatok magára a helyszínre, kontextusra vonatkoznak. A fókuszcsoportok vizsgálat célja valamilyen adott téma, a fókuszcsoport mint terepmunka célja viszont maga a fókuszcsoport.

31.

A szakirodalom egyszerre értékeli a terepmunka mint sajátos kutatási mód lehetőségeit, illetve hangsúlyozza a korlátait. Ez utóbbiba tartozik például az autoritás kérdése. Mennyire hat a például terepkutató által képviselt intézmény, a kutató társadalmi helyzete a helyszínre? Hozzá kell tenni, hogy ez nemcsak a terepmunka esetében jelentkezhet, hanem valamennyi emberekkel folytatott, kommunikatív technika során is (például interjú, fókuszcsoportos vizsgálat esetében). A terepmunka során ugyanakkor nem szükségszerü ennek a hangsúlyos jelenléte.

A terep, a résztvevő megfigyelés részben a megmentés (dokumentálás), részben a feltérképezés céljából látszik igazán hatékonynak (Small 2009). A terepkutatás eredménye az antropológián belül klasszikus formájában az etnográfia. Ez a müfaj a vizsgált jelenségeket kontextusba helyezve írja le (alapvetően szövegként). Maga a kontextus ugyanakkor sokféleképpen jellemezhető: egyaránt lehet például sűrü, lokális, émikus, belső leírás a megjelenési formája (Forster 2012:10). A terepmunka kritikája hatására ugyanakkor az eredmények közé számít az 1990-es évektől kezdve a terepnapló, a terepjegyzet is (Sanjek ed. 1990). Illetve mára az előbbi jellemzők is valamilyen mértékben (és folyamatosan) átértékelődnek (lásd az olyan fogalmakat, mint „ritka”, „hibrid”, „globális”). A sürü és ritka (,thick” „thin”) leírás megkülönböztetésének hangsúlyozása mára sok szempontból visszaszorulóban van (Brekhus et al 2005), fóképpen abban az összefüggésben, hogy sokáig a „sürü” a terepmunka és az értelmező antropológia alapvető szinonimájaként szerepelt a geertzi interpretív antropológia hatására. Manapság a ritka leírás egyre kevésbé tưnik annyira másodlagosnak és így kihagyhatónak a terepmunka tekintetében, mint korábban gondoltuk (Descombes 2002:444). Emellett éppen az egyre fontosabb terepjegyzetek, képi terepdokumentációk is alapvetően ritka leírásúak, vagy legalábbis jóval inkább azok, mint maga a sưrü etnográfia, mégis elég gazdagok a terep dokumentálásához. 33.

Mi a közös tehát a terepkutatásokban mint technikában? Részben a környezet, helyzet által biztosított empirikus bizonytalanság, komplexitás, nyitottság. Részben viszont magának a technikának a nyitottsága. A terepkutatás révén az adott helyzetnek bármilyen vizsgálata lehetséges, lehet hosszú vagy rövid ideig jelen lenni, témát vagy összefüggést keresni, dokumentálni vagy új dolgokat felfedezni. 
Lehet a közelben dolgozni, vagy minél távolabbi helyen kutatni. Lehet tágabb körben, például egy faluban, településen vagy városrészben, de ugyanígy lehet egyetlen háztartásban, egyetlen személy környezetét követve alkalmazni. 34 .

A terepmunka a közvetlen, közeli, helyszíni jelenlétet használja ki. Ennek erősebb változata a résztvevő megfigyelés. Itt nem csupán ott van az ember, hanem a számára érdekes jelenségek időbeli, térbeli, társadalmi kontextusához is hozzáférhet (valamilyen mértékben és módon). A terepmunka ellentéte ily módon a távoli, közvetett hozzáférés (például megfigyelés, interjú). Így például egy mélyinterjú is lehet nyilvánvalóan nem terep jellegü, ha nem az adott téma szempontjából érdekes kontextusban történik meg.

\section{Történetiség}

35 .

A történetiség triviálisan nézve a terepmunkának elválaszthatatlan része, éppen az idóbelisége révén. A terepen minden változik, ahogyan telik az idő, vagy ahogyan újabb és újabb terepmunkák követik egymást. Az igazi kérdés azonban ennek kontrollálhatósága. Mennyiben hat a terepmunka során szerzett ismeretekre a helyszín, illetve a kutató változása? Ennek egy része követhető (például éppen a tárgyi környezet (át)alakulása, ez a háttérismeretek esetében azonban jóval kevésbé látható. A terepmunka történetisége azonban a tudomány(ok) oldaláról nézve is fontos összetevő.

36.

A terepmunka a 19. század közepétől máig folyamatosan jelen van a természet- és a társadalomtudományos kutatási technikák tárában, noha koronként eltérő hangsúllyal és jelentőséggel. Kialakulása és elterjedése egyértelműen a természettudományokon belül, közelebbről az orvostudomány és a zoológia területén keresendő a 19. században. A társadalomtudományokban, bár néhány úttörő kezdeményezés vissazkövethető a 19. század közepéig, csupán a 19. század végén, majd a 20. század elején terjedt el, és vált azután az egész antropológia identitását meghatározó technikává. Jelenleg sem csökkent a szerepe, emellett az alkalmazott tudományok és az elmélet határmezsgyéjén továbbra is számos tudomány képviselői élnek vele (lásd laborvizsgálatok, robotika, TESLA-tervezés). Bizonyos természettudományos vizsgálatokban ráadásul legalább annyira hangsúlyos ma is, mint az antropológiában (például a primatológiában), és az alkalmazásának mai térhódításában (lásd laboratóriumkutatás) nem kis szerepet játszik a társadalom és a kultúra fogalmának ANT (cselekvőhálózati) jellegü kitágítása, illetve átértelmezése.

Egyik legkorábbi klasszikus módszerű terepmunka, mely már a természet- és a társadalomtudományok határán mozgott, John Snow angol orvos On the mode of communication of Cholera (1855) munkájának és ennek alapját képező kutatás képezte. Snow ugyanis meg akarta tudni, hogyan terjed a kolera. A betegek és az egészségesek, illetve a betegek és a környezetük (épületek, lakások, csatornák, kutak, ivóvízforrások) közötti kapcsolatokat tanulmányozta a helyszínen. Ennek alapján sikerült azután elsőként feltárnia a kolera mint fertőzés hátterében müködő mechanizmust (Desmond 2014:565). 38.

Klasszikus értelemben a terep, mint láttuk, a „természetes” („természeti”) helyszín, a megszokott módon múködő és egymással kölcsönhatásban levő jelenségek közege volt az önállósodó antropológián belül (Gupta - Ferguson 1997:7). Bár a 
résztvevő megfigyelés mint a terepen végzett antropológiai megfigyelés születését sokszor Malinowskihoz kötjük, nem szabad elhanyagolni ebben a folyamatban a zoológia hatását sem a 19., század végén; ezáltal „válhatott” az antropológia természettudománnyá a 19. században. Bizonyos terepek ugyanis jobban garantálták a természetközeli állapotokat a kor evolucionista érdeklődésü antropológusai számára. Az akkori elképzelés és remény szerint ennek révén lehetett jobban rekonstruálni az „eredeti”, „természetes” állapotokat. A terep itt az iparosodott hellyel (például város, gyár, laboratórium) állt szemben (Gupta - Ferguson 1997:8). 39.

A terep mibenléte minden esetben egy tágabb tudományos világképnek a része. A terep ideája ugyanakkor behatárolhatja a terepmunka helyét, és ennek révén a megszerezhetó ismeretek jellegét (Gupta - Ferguson 1997:15). Azaz, ami nem lokalizált, nem helyhez kötött (tehát nem a helyi közösségre jellemző), a klasszikus terepfelfogás értelmében eleve kiesik mint helyszíni kutatási lehetőség. Sokáig ilyennek számítottak például a média, transzlokális szervezetek, vállalatok (Gupta - Ferguson 1997:15). Ahogyan Geertz (1973:22) fogalmazta meg: „Anthropologists don't study villages...; they study in villages”, azaz „Az antropológusok nem falvakat vizsgálnak, hanem falvakban vizsgálódnak". 40 .

A terep ilyen jellegü értelmezésében azok a jelenségek, helyszínek, melyek nem otthonosak, antropológiainak számítanak; amik viszont igen, azok eleve kimaradnak ebból a körből (Gupta - Ferguson 1997:16) (ilyen például a tévénézés, kórházi kezelés, iskola). Mi újat tudhatnánk meg ugyanis annak vizsgálatával, amit eleve ismerünk? A klasszikus antropológiai kérdésfeltevésben a távoli hordozta az újat, és ez az új azután számos modellben találta meg a helyét.

A klasszikus, hosszú távú, résztvevő megfigyelésen alapuló terepmunka és etnográfia feltételezi például a kultúra egységes, organikus voltát (Escobar 1993:381) (ez a nézet szorosan kötődik a Malinowski-, Mead-, Benedict-féle strukturalistafunkcionalista kultúrafelfogáshoz), mely szerint az általános társadalmi működés, minta megértéséhez az aktuális társadalmi kapcsolatok múködésének megfigyelésével lehet közelíteni. Ezzel a képpel állt szemben az evolucionista és a diffuzionista megközelítés az antropológia korai korszakában. A terepmunka fordulat, azaz klasszikus terepmunka technikának a középpontba kerülése az antropológián belül (lásd Malinowski) és erősítette az empirikus kutatások körét és mélységét, egyben leszúkítette a teoretikus vitát a lokalitásra és a jelenidejüségre, éppen a diffuzionista és történeti kérdések háttérbe szorításával (Gupta - Ferguson 1997:20). 42.

Ebben a keretben a brit terepmunka tradíció - érthető módon - kezdetben sok tekintetben inkább természettudományos jelleget viselt (a közvetlen megfigyelést, a természetes közeget hangsúlyozva), a korai amerikai, azaz boasi kutatási (terepmunka) modell viszont inkább szöveg alapú, erősen történeti (rekonstrukciós) típusú, megmentő szándékú volt, és módszertanilag hamar eklektikussá vált (Gupta - Ferguson 1997:21). Az egyik kiutat ebból a historizáló megközelítésból nem sokkal később az akkulturáció vizsgálata kínálta fel az amerikai antropológián belül (Gupta - Ferguson 1997:22). 


\section{Problémák, kérdések, fogalmak}

43.

Sokáig (egészen az 1970-es évekig) reflektálatlan eszköz maradt a terepmunka (Rabinow 1977, 2006; Gupta - Ferguson 1997). Az azóta napvilágot látott elemzések ellenére máig számos nyitott kérdés övezi. Ilyen például a „terep”, a helyszín kiválasztása; a vizsgálandó problémák azonosítása; a terepmunka közben alkalmazott fogalmi keret. Honnan tudja az ember, hogy a kiválasztott probléma valóban probléma-e, és hogy a kiválasztott hely alkalmas-e a probléma tisztázására (Rees 2007:57)? Valójában milyen kontextusok mentén találkozik a kutató és a kutatott, illetve (pontosan) mi is történik e találkozások során? Ezek a kérdések ma alapvetően módszertani jellegüek, de a reflexiók és az ezzel párhuzamos kritikák gyökere a posztmodern ismeretelméleti kérdésekig vezethető vissza. 44.

Az antropológia, az antropológiai tudás és ismeretszerzés általános kritikája egyértelmüen kuhni indíttatású volt az 1960-as évek végén (lásd Scholte 1983), melyhez a frankfurti iskola által képviselt, társadalmi jellegű bírálat is csatlakozott. Az antropológia reflexív fordulata mint megközelítés nem véletlenül először Bob Scholte (1969) írásában bukkant fel (lásd Rapport - Overing 2000:19), az antropológiára jellemzőnek vélt és bírált politikai aszimmetria formájában. 1986-ban ez a vonal szélesedett azután ki (Clifford - Marcus eds. 1986; Marcus - Fischer eds. 1986), a Writing culture ennek mentén reflektált nemcsak a reprezentáció hatalmi vonatkozásaira, hanem az antropológiai autoritásra is a terepmunka során. 45 .

A posztmodern kritika tehát alapvetően a tudósok mint közösség, az antropológiai tudás hátterében meghúzódó abszolút vagy autoratív tudás ideájának problematikájával kezdett el foglalkozni a tudomány különböző területein belül (lásd Linstead 1993:97-98: Kuhn 1962 és Hassard 1990 müveire hivatkozva; Mutman 2006). A tudás hirtelen relatívvá vált. Ez pedig megkerülhetetlen kérdéssé tette az együttmúködést és a dialógust a terepmunka és annak feldolgozása során. 46.

Az együttmúködés iránti igény részben etikai hátterü, azaz a kutatásban, gyüjtésben, értelmezésben érintetteknek joguk van valamilyen módon, szinten és mértékben hatni e folyamatokra, részben azonban módszertani alapon nyugszik, hiszen jelenleg úgy látszik, a kutatottakkal együttmúködve jobb eredmények születhetnek e területeken. A mai kollaboráció igénye ugyanakkor a terepkutatáson belül inkább ökológiai jellegü, nem pedig etikai hátterü (Rabinow 2010:5). Az egyik új igény ezzel kapcsolatban: nem csupán a Másik nézete a saját életvilágáról, hanem a Másik és az antropológus ehhez való interaktív viszonyulása (Escobar 1993:383). Ez egyfajta elmozdulás a „résztvevő megfigyeléstől” a „részvétel megfigyeléséhez” (Tedlock, Barbara 1991), egyben a „narratív etnográfia” születése.

A kollaboráció igénye ennek ellenére az egyéni terepmunkával kapcsolatos kritikából alakult ki az antropológián belül az 1970-es években (Rees 2007:55). Amellett érveltek a bírálók, hogy a tanulmányozott kultúra összetettsége és az egyéni kutatói elfogultság torzíthatja az eredményeket. Itt tehát a kutatók közötti együttmúködés került az előtérbe. A kritika szerint a mai kultúrakutató, társadalomtudományi szakok még mindig a 19. századi szervezettségükben múködnek, nincsenek ráutalva az interdiszciplináris együttmúködésre és kísérletezésre (Rabinow 2006). Lassiter (2005) szerint viszont a valódi részvétel az antropológiai kutatásban a kognitív antropológiában kapott először kitüntetett szerepet, az émikus-étikus megközelítés közötti eltérés fogalmi bevezetésével. Ha ugyanis létezik egyfajta 
külső nézőpont és fogalmi keret, mely általában a kutatóé, és emellett van belső látásmód is, akkor ez utóbbi rekonstruálásában nehéz elvonatkoztatni maguknak a résztvevőknek a véleményétól. 48.

A dialógus új paradigmája először az 1970-es, majd 1980-as években fogalmazódott meg az antropológián belül (Rabinow 1977; Tedlock 1979; Dumont 1978; Crapanzano 1980; Dwyer 1982), ezeket összegezte azután Clifford (1988:39-46). Az antropológiai tudás ennek megfelelően a határterületen, a „kontaktzónában” létezik, tehát az antropológus és az adatközlő között. Az ekképp kialakult tudás ily módon mindkét fél számára új (bár valószínúleg nem egyenlő mértékben, módon és nyelven); egyfajta közös, megosztott világ, megértés (Rapport - Overing 2000:116-117). Stephen Tyler (1987) szerint éppen ezért az etnográfiának (terepmunkának és esettanulmánynak) eleve dialogikusnak és kollaboratívnak kell lennie, egészen a szöveg elkészítését beleértve (Rapport - Overing 2000:238). 49.

Azt is figyelembe kell venni azonban, hogy a terepmunka idóbeli folyamat, eltérô szakaszokkal. A terepen a terepjegyzetek készítésekor például jóval gyakrabban előfordulhat egyfajta oda-vissza kapcsolat, kollaboráció, formálódás, mivel ez a helyszínen történik (Bakos 2018). Felmerülhetnek kérdések, kételyek, ez pedig párbeszédre késztetheti a kutatót. Az etnográfia írása esetében azonban általában éppen ez a közvetlenség, közelség hiányzik (Astuti 2017:10), bár ennek alkalmazása önmagában itt sem megoldhatatlan, fóképp az utóbbi évtizedekben. 50.

Az antropológiai reprezentáció krízisére adott válaszok egyike a kísérleti antropológia (új etnográfia) formájában jelent meg. Richard Fox (1991) Recapturing anthropology. Working in the present kötete ennek szellemében az antropológia mint terepmunkán (és etnográfián) alapuló „művészet” (artisanship) metaforáját kérdőjelezi meg. Szerinte ehelyett a (z ipari, kapitalista) „gyáa”, „üzem” (factory) metafora sokkal jobban illek arra a helyzetre (ami sokkal több a terepmunkánál és az etnográfiánál), amikor nem az antropológus uralja az alkalmazott eszközeit (Escobar 1993:378). Ebben a kritikában hangsúlyos, hogy nem a szöveg belső politikájával kell kizárólag foglalkozni, hanem a szöveget körülvevő politikával is (melynek kontrollja kívül esik az antropológus hatókörén). 51.

Amin túl akar lépni ez a kritikai megközelítés, az egyértelmúen a geertz-i kultúrakép mint szöveg; a szöveg alapú stratégiákon mint dialogikus és polifonikus etnográfián; a „másik” „reprezentálásának” mikéntjén. A kérdés: hogyan tud az antropológia belépni a valós világba?

Az antropológia általános krízise tehát jól láthatóan nem egyszerúsíthető le a reprezentáció krízisére (lásd új muzeológia is), az írásra. A politikai és társadalmi kontextus ebből ugyanis kimarad, és ez megnehezíti az STS (Science and Technology Studies) és hasonló, nem antropológiai praxisvizsgálatokkal való kapcsolatot (Pels - Nencel 1991:7). 53.

Az antropológiai terepmunka ilyen irányú újragondolásának az egyik eredménye (Pels - Nencel 1991:7) az akcióantropológia térnyerése lett. A kritika alapja ugyanakkor továbbra is az antropológiai autoritás kérdésének problematizálása és az ezen alapuló viszony „összeomlása” maradt, nem pedig az elméleti megalapozás hiánya (Pels - Nencel 1991:9). Az antropológiai, kutatói autoritás köre és mértéke 
ennek megfelelően tovább zsugorodott az 1980-as évek reflexiói nyomán (Ortner 1984).

54.

A terepmunka krízisével kapcsolatban óhatatlanul felvetődik továbbá a szimmetria, az egyensúly elvének kérdése, mely nem teljesen független az autoritás problematikájától. Mennyire spontának például a megfigyelt helyzetek vagy a kapott válaszok, magyarázatok?

Ebben az összefüggésben a konstrukció (nyelvi játék) kérdése szintén az egyik központi elemévé vált a posztmodern terepkutatás kritikájának. Tagadhatatlanul sok formában, számos esetben jelen van vagy éppen jelen lehet a terepmunka során és ennek eredményeiben, nem ritkán rekonstrukciók formájában (például filmek, fotók, történetek), és előfordulhat gyüjtött tárgyak esetében is (lásd „mondvacsinált” tárgyak, makettek, modellek). A konstrukció e felfogásban sajátos, valóban közös múfaj eredménye (ahol a kontroll ugyanakkor még mindig széles palettán mozoghat), ám nem mindig reflektált, és nehezen illik bele a klasszikus keretbe. A helyén lehet kezelni, de csak akkor, ha világos a kontextus. A terep sokféleképpen hat vissza, változik a részvétel hatására (looped, lásd Hacking 1999; Malik 2017; Hauswald 2016). Ez vonatkozhat a leírásra, de magára a jelenségre is. A kettő azonban nem feltétlenül függ össze.

56.

A terepet ugyanakkor érdemes realista alapon kezelni: valahol az esszencializmus és a konstrukcionizmus között egyensúlyozva. A jelenségek magyarázatára szolgáló terminusok ugyanis mások, mint az adatok magyarázatára szolgáló terminusok (Malik 2017:90). A jelenségeknek stabil, ismétlődő jellegzetességei vannak, ezek számos, és nagyon eltérő adattípusokból (és eltérő eszközök alapján) következtethetők ki. A jelenségek mögött általános magyarázatok állnak, az adatok mögött partikulárisak (Malik 2017:91). Ahogyan sokfajta adatféle rajzolja körül (írja le) a jelenséget (mint minta), adott adat sokféle jelenségre vonatkozhat. A jelenségek leírása elméletfüggő, mivel a jelenséggel kapcsolatos tudásunk az elmélet része (háttértudás, észlelési adottságok, episztemológiai korlátok), de maga a jelenség nem elméletfüggő (hanem inkább emberfüggő) (Ströing 2018:190). A jelenségek okozzák a megfigyelést.

A Mészáros Csaba-féle (2016:25-26) wittgensteini nyelvi játék típusú értelmezés igazából akkor vonatkoztatható a terepmunka helyzetére, ha valóban együttmúködés során alakul ki valamilyen tudás a kulturális életről, azaz ha az antropológus a megfigyelttel együtt alakítja az adott téma értelmezését, antropológiai leírását. Abban az esetben azonban, mikor a kutató a szubjektív tapasztalatai alapján rekonstruál egy „kultúrát”, szubkultúrát, életvilágot stb., akkor itt egyéni következtetésekről, megfigyelésekről van szó. 58.

Noha a tapasztalat szerzése dialogikus módon és cseréken keresztül jön létre, azaz részt vesznek benne mások is. A jelenségek, események ugyan közös környezetben keletkeznek, alakulnak, ezek rögzítése (data record) azonban egyéni és perspektívikus a hátterek miatt (lásd Massimi 2015) Ez akkor sem egyszerü, ha a kutató egy (több) helybelivel igyekszik rekonstruáltatni az életvilágokat. Itt ugyanis legalább annyira foglalkozhat utána ezzel a lokális rekonstrukcióval (mint téma) (azaz akkor ez alapján rekonstruálja a lokális rekonstrukciót), illetve messze nem egyértelmú, hogy valójában ez a fajta lokális rekonstrukció volna a terepmunka 
célja, és hogy ez felülírja a kutató szubjektív tapasztalata, háttere (érdeklődése, eszközei, céljai, érdekei) alapján rekonstruált kultúrát. Megint nem ugyanaz, ha a külső kutató együttmúködik belső kutatókkal e célból. Ebben az esetben azonban a közös nyelv megtalálása mint cél biztosan az előtérbe kerül. 59.

A terepen való ottlét, a megfigyelés és részvétel mindenképpen együtt jár olyan jellegú kommunikációs formákkal, melyek éppen e kapcsolat révén alakulnak ki. Ha az antropológus részt vesz egy adott rítuson, azt olyan keretben teszi, teheti, mely egy idegen számára meghatározza, mit tehet és mit nem. Nem ritkán már eleve léteznek ilyen minták a csoporton belül, de ha teljesen új a helyzet, létre tud/szokott jönni. Az igazi kérdés azonban, hogy ez mennyire hat a megfigyelni szándékozott eseményekre. Ha megengedik egy idegennek, hogy egy konkrét Naptáncon részt vegyen, maga a Naptánc, illetve a megfigyelése (és leírása) ettől valóban közösen 60.

létrehozott, nyelvi játék jellegú eseménnyé válik?

Ez nem jelenti azt, mint láttuk, hogy a terepen ne alakulnának ki nyelvi játékok. A nyelvi játék ráadásul bizonyos megközelítéseknek akár a célja is lehet. Az együttmúködésen alapuló terepmunka kapcsán látni fogjuk, mennyire ez a fajta kommunikáció kerül a középpontba, mely újabban az etnográfiának mint az antropológiai leírásnak egyik újfajta minőségét is képviseli adott nézőpontból (Lassiter 2004). Ám ez a fajta ismeret egyértelmüen (re)konstrukció, akár az antropológus (kutató) alakítja ki (klasszikusan egyedül), akár a megfigyelt csoport egyes képviselőivel együtt (mint újfajta, gazdagabb etnográfia). És fontos észrevenni, hogy mindez egy ezt megelőző tapasztalaton, megfigyelésen és adatlétrehozáson alapul. Vagyis ép61. pen a terepmunka lényegét nem érinti.

A terepen szerzett ismeretek, tudások ismeretelméleti státuszát ugyanakkor szintén kapcsolatba lehet hozni a wittgensteini nyelvi játékkal, azaz amellett is lehet érvelni, hogy nem csupán az értelmezés, hanem maga a megfigyelés (és adatnyerés) szintén nyelvi játék jellegư, vagy a nyelvi játék hatásának kitett jelenség. Ettől nem teljesen független az az érvelés, mely szerint e megfigyelések elméletfüggők. $\mathrm{Az}$ (antropológiai) adatok (tárgyak), illetve általában bármilyen megfigyelés elméletfüggősége azonban valószínúleg sokkal kevésbé drámai hatású (Mészáros Csaba [2016:25-26] érvelésétől eltérően), mint azt korábban gondoltuk. Az adatok ugyanis sokkal inkább adatmodellekbe illeszkednek, és kevésbé elméletekbe. Az elméletek ugyanakkor jelentős mértékben hathatnak a kutatási terület, téma, hely kiválasztására, a vakfoltokra, függetlenül az ott tapasztalt dolgoktól. Számos példa létezik az antropológiai terepmunkák vakfoltjaira. Ilyen volt Malinowski számára a munkamigráció megléte; Redfield szemében a zapatisták jelenléte; vagy a franciák (valós) jelenléte, illetve (etnográfiai) hiánya a geertzi Marokkóban (Rabinow 2010). Ha az okokra vagyunk kíváncsiak, szinte minden esetben érvelni lehet amellett, hogy ez észre vagy figyelembe nem vett jelenségek mögött az adott korszak és iskola paradigmái állnak. 62.

Fontos probléma továbbá a terepmunka episztemológiai átláthatósága. Vajon mennyire kaphatók, érhetők el ilyen helyzetekben, a terepen helyi értelmezések (lásd Mutman 2006 is)? Úgy látszik azonban, hogy az értelmeztetések nem feltétlenül kapcsolódnak szorosan a terepmunkához, azaz ezek az interpretációk akár más környezetben is múködhetnek. Külön kérdés azonban, milyen hatással van minderre a terep. Illetve mennyire szorulnak a terepen hozzáférhető értelmezések 
további értelmezésekre? Mennyire jó leírások ebből a szempontból a „sűrü leírások”? Vagy esetleg jobban használhatók hosszabb távon a „ritka leírások”? 63.

Ha pedig részvételről, résztvevő megfigyelésről beszélünk, akkor vajon miben vesz részt a megfigyelő? Az értelmezésben, a cselekvésben, társadalmi folyamatokban stb.? Miben tud részt venni, és miben nem? Vajon a megfigyelések valóban csak az adott helyzetben, kontextusban értelmezhetők? Vagy akár kontextusok között is? A kontextusba minden esetben beletartozik-e a helyi értelmezés? 64.

$\mathrm{Az}$ antropológiai terepmunka egyik alapkérdése azonban továbbra is nyitott. Mi történik a találkozás, a résztvevő megfigyelés során? A klasszikus válasz a kutató és a kutatottak kulturális különbségét hangsúlyozza, magából a kulturális találkozásból indul ki, és a terepmunka lényegét a Másik kultúrájának (valamilyen szintű) elsajátításában, az eltérő kultúrába való szocializálódásban, az adott életmódba való belemerülésben, az ezzel kapcsolatos kulturális kompetencia elsajátításában (tulajdonképpen az émikus nézőpont megtanulásában) látja (Collins 1984; Austrin - Farnsworth 2005:150; Candea 2019) 65.

Egy másik lehetséges válasz jóval kevésbé támaszkodik a kultúrák különbségére és ezek találkozására. Ez a megközelítés sokkal inkább a tudományos megfigyelés jellegéből indul ki, azaz a kutató a saját tudományának hátterére (paradigmájára, módszertanára, elméleteire, hipotéziseire, addigi ismereteire) támaszkodik, és valójában ezt igyekszik leképezni a terepen tapasztalt, megfigyelt jelenségekre, illetve ezt próbálja meg módosítani e jelenségek hatására (Austrin - Farnsworth 2005; Candea 2019). 66.

Jól látható, hogy a kétfajta nézet radikálisan másképpen írja le a terepmunka múködését. Ha a nyelvtanulást metaforáját használjuk, akkor a klasszikus szemlélet az idegen nyelvi közegben való nyelvelsajátítást veszi alapul, ahol a tanuló anyanyelve és egyéb általa ismert nyelv áll szemben az idegen nyelvvel, és ez utóbbi fokozatosan válik az első kör részévé. Ebben a tanulási folyamatban a tanuló egyre jobban tudja alkalmazni az idegen nyelvet, az újonnan elsajátított nyelv nyelvtanát azonban nem (feltétlenül) ismeri (kifejtetten). A másik megközelítés ezzel szemben abból indul ki, hogy ha valaki egy idegen nyelv grammatikájára kíváncsi, akkor eleve valamilyen általánosabb szintü nyelvtant kénytelen alkalmazni. Akár megtanulja a nyelvet, akár nem, e nyelv szerkezetének megismeréséhez szüksége van valamilyen elméleti háttérre, modellre, mely a nyelvészetból mint tudományból származik. A terepmunka (célja) ebben az értelemben tehát nem kultúraelsajátítás (kulturális kompetencia megtanulása), hanem a kultúrával, életmóddal kapcsolatos tudományos kérdések tisztázása.

Fontos észrevenni továbbá, hogy a terepmunkával kapcsolatos alapproblémákra e két megközelítés eltérő válaszokat ad, ugyanakkor érintetlenül hagyja a közvetlen, helyszíni, nyitott megfigyelést mint technikát, azaz itt nincs eltérés a kétfajta modell között. Az érintett, másképpen kezelt kérdések közé tartozik például a terepre érkezés utáni „kultúrasokk”, a terepnek (a téma tekintetében való) „bizonytalansága”, a „kulcsadatközlők” szerepe vagy a „helyi etnográfusok” lehetősége, a „fordítás" problémája.

68.

A terepmunka kezdetén bekövetkező „sokk” a klasszikus terepmunka előkészítés és beszámolók visszatérő témája. Az antropológust eszerint egy radikálisan más, 
idegen kultúrával találkozva drámai hatások érik, egészen addig, míg bele nem illeszkedik az adott kultúrába. A klasszikus nézőpont ezt a különböző kultúrák közötti távolságnak tulajdonítja, és gyakorlatilag adottnak látja a terepmunka elején, a paradigma alapú megközelítés szerint azonban ez az idegen, szokatlan környezet hatása, és csak esetlegesen a másik kultúra következménye. Például az új hely zsúfoltsága vagy az ottani zaj mértéke bármely típusú utazót, odaérkezőt zavarhat, de ezek a hatások sok esetben nem kulturális jellegűek (a kultúra egyetlen értelmezésében sem).

69.

A klasszikus terepmunka hangsúlyozza a terepre érkező antropológus bizonytalanságát azzal kapcsolatban, mi iránt fog érdeklődni, mit fog megfigyelni, gyújteni. A paradigmatikus nézőpont szerint a terepmunka tehát megkövetel ugyan egyfajta tematikai nyitottságot, ezt azonban nem strukturálatlanul követi a kutató (Rees 2007:19), mivel minden esetben ott van a hátterében a tudománya paradigmája (Candea 2019).

70.

A „kulcsadatközlők” a klasszikus változatban az antropológus szorosabb kapcsolatai közül kerülnek ki, akik a helyi és az antropológus kultúrája között közvetítenek. A paradigma jellegű modellben ezek azok, akiknek az adott tudományos kérdés (például hogyan, milyen tudás alapján tájékozódnak a helybeliek az adott környezetben) tekintetében van hozzáférhető ismeretük. Ráadásul a klasszikus nézet szerint valójában sokkal célravezetőbb volna eleve helyi, „őslakos etnográfusokat” alkalmazni, ahelyett hogy évek alatt ismeri meg az antropológus valamilyen szinten a helyi nyelvet, életmódot, környezetet. A pardigmatikus szemlélet szerint azonban ez nem olyan egyszerü, hiszen a megfelelő kutatáshoz a terepen a tudományos modellekre, kérdésekre, ismeretekre legalább annyira szükség van, mint a hely (nyelv, kultúra) ismeretére.

71.

A kutató hátterének a pontosabb meghatározása, vagyis, hogy az antropológus kutatás közben a tudományának eszközeire támaszkodik, annak modelljeiből indul ki és ehhez képest igyekszik értelmezni a terepen megfigyelteket, pontosabb válaszokat képes adni arra, mi a valódi különbség az émikus és az étikus leírás között (azon túl, hogy az egyik belső és másik külső). Emellett érveket tud adni a ritka leírás alkalmazhatóságára (az adatmodellek időtállóságára hivatkozva az értelmező modellek mulandóságával szemben). Ezen kívül jobb megközelítésnek látszik azzal a problémával kapcsolatban, amikor a helyi „kultúra” belsőleg sokrétű, vagyis egy adott csoporton belül sokféle, egymástól eltérő és gyakran ellentétes kulturális modellekkel szembesülünk (Ventura i Oller 2000). E sokrétűség megléte ráadásul újragondolásra késztet bennünket a „kulturális határok”, a „kulturális tartalmak”. az „egyén”, a „,személy”, a „társadalmi és etnikai egység” fogalmaival kapcsolatban (Ventura i Oller 2000:61). És e fogalmak mind az adott tudomány paradigmáin nyugszanak, és nem a kutató saját kultúráján (bármi legyen is az).

\section{Terepmunka és múzeum} 72.

A múzeumi antropológia és a terep viszonyának elemzésekor az egyik lehetőség, hogy a korábban tárgyalt, a terepmunkát általában jellemző fogalmakat, problémákat megnézzük konkrétan a tárgyak gyújtésére és muzealizálására kihegyezett antropológiai munkákban. 
73.

Nem tárgygyújtésen alapuló tárgykutatások (terepen) természetesen a gyưjteményképzésen kívül is léteznek (lásd például Knez 1997; Hahn 2005); a FélHofer-féle Átány-kutatás például egyszerre volt néprajzi jellegü, tárgyorientált vizsgálat és tárgygyưjités, különböző átfedésekkel. A terepen való antropológiai tárgygyưjtés önmagában lehet egy, az anyagi kultúrára összpontosító kutatás része, vagy lehet egy, a helyszínen történő gyưjteményképzés eredménye. A kettő olykor eltérő módon jön létre és müködik. A fő különbség valószínúleg nem feltétlenül a gyüjtött anyag összetétele, hanem a kontextus ismeretének mélysége. Ugyanakkor ez is viszonylagos különbség. A 19. század közepén és végén a nagy magángyưjjtők (például Godeffroy 1860-tól), majd az európai múzeumok egyaránt elkezdtek kontextuális információkat gyưjtetni, gyújteni (Haddon 1898, illetve német múzeumok, főleg Berlin), illetve éppen ezért a hosszú távú terepmunkát kezdték propagálni (Kaufmann 2015). Ez ellen hatott azonban az első vh. idején és után az a változás, hogy az egyetemi, oktatási célú gyưjtemények végleg elszakadtak a tanszékektől és ily módon az oktatástól (ennek révén sok esetben megszűntek vagy múzeumba kerültek), az eleve múzeumi formában létező gyüjtemények pedig elszigetelődtek az oktatástól (Kaufmann 2015:23). 74.

Mi indokolja azonban ma a kutatói helyszíni, résztvevő megfigyelés alapján történő vizsgálat kiegészítését tárgygyưjitéssel? Részben a bemutatás igénye; részben azonban például a tárgyak biográfiája mint kutatási irány, megközelítés. Ha ugyanis a tárgyak magukon viselik életük nyomait (rétegzettek), ezek megfelelő módszerekkel felfejthetők. Minél aktívabbnak képzeljük a tárgyakat a társadalmi életen belül, minél egyenrangúbb szereplőknek tekintjük őket, annál jobban kutathatók (önmagukban is), annál inkább túllépnek az illusztrációként vagy dokumentációként való jelenléten. A tárgyvizsgálat emellett bizonyos esetekben valóban együtt jár a tárgy kiemelésével (gyưjtésével). Ilyen például az összehasonlítás, megmentés, tárgyként való dokumentálás.

Azt, hogy valójában van-e lényeges eltérés a gyüjtéssel együtt nem járó tárgyvizsgálat és a gyüjteményképző kutatás között a terepmunka szempontjából, nehéz megmondani. A gyưjitemény kiválasztása és ezek megszerzése egyértelműen más, mint a helyszínen való megfigyelés, értelmezés, sok esetben eltérő kapcsolatokat feltételezhez, de hogy ez mennyiben érinti magát a megfigyelést, az értelmezést, ezek tartalmát, az nyitott kérdés. A tárgyak helyszínen vagy terepen való gyưjiése ugyanakkor nem feltétlenül esik egybe az aktuális használatukkal kapcsolatos részvétellel. Gyakran éppen ennek megszűnése könnyíti ezt meg. Ráadásul ez nem feltétlenül jelenti, hogy ne lennének hozzá megfelelő ismeretek. 76.

A gyüjtés, gyüjtemény (múzeum) és az antropológia kapcsolata, mint láttuk, fontos volt az antropológia kialakulásának első évtizedeiben. Az antropológiai muzeológia és a jelentős expedíciós tárgygyüjtések klasszikus korszaka nem véletlenül, több oknál fogva az 1860-1920 közötti évekre tehető. Ez a fajta terepmunka azután az 1940-es évektől csak elvétve marad divatban (megint csak számos okból). Az egyik utolsó ilyen jellegű nagyszabású antropológiai gyưjités valószínúleg az 1948-as amerikai-ausztrál tudományos expedíció volt Arnhem-földön (Harrison 2013:93). 
A múzeumok többsége a 19. század végén a képként (tárgyként) megmentett múltat gyűjtötte össze a hagyományt vesztett jövő számára mint absztrakt szociálarcheológia (Morris 1994:80, 89). A kor és hely egyetlen kivétele a Sheldon Jackson Museum volt (Alaszkában, Sitkában müködik misszionárius múzeumként, 1887 óta), mely maguk az őslakosok számára gyưjtött (Miller 2004:184-185). A korai terepmunkás gyưjjtők emellett általában természettudományos képzettségűek (gyakran zoológusok, később fizikai antropológusok) voltak, akik típusokat és változataikat keresték (nem pedig véletlenszerüen gyưjiöttek). 78.

A terepkutatás kezdete a múzeumantropológián belül (Bennett, in Harrison 2013:56-57) nagyszabású, hosszabb idejű múzeumi indíttatású tárgykutatásokhoz és -gyưjtésekhez kötődött: ilyen volt az óceániai Haddon-expedíció (1898); a Spencer - Gillen-féle ausztrál (1896-1897), az arktikus Jesup-expedíció (18971902), de kezdeti kutatásai során Franz Boas is foglalkozott tárgygyüjtéssel terepmunkái során (lásd lentebb). A szándék minden esetben azonos volt: a távoli, más társadalmak életmódjának „begyüjtése” és megmentése (a tudomány számára) az anyagi kultúra révén. Nem szabad elfelejteni, hogy az akkor divatba jövő cenzusok is hasonló célúak voltak (lásd Bennett 2013, in Harrison 2013). 79.

A Torres-Strait vidékén dolgozó Haddon-expedíció (1898) az adott korban egészen modernnek mondható technikákat alkalmazott: számos tudomány képviselője múködött együtt, intenzív film- és fotódokumentációt folytatva. Haddon az ily módon összeállt dokumentációt, a korban úttörő módon kommentáltatta a helyiekkel. Nemcsak mintegy ezer tárgyat gyưjtöttek össze tehát a résztvevők, hanem ezek publikálásakor idézték a helyiek megjegyzéseit is. Ezt a korban szokatlan igény(esség) tette fontossá, ésa helyiek közül kiválasztott asszisztensek alkalmazása tette lehetővé. Az expedíció ennek következtében sok tekintetben ellentmond a 19. század végi antropológiai kutatásokkal kapcsolatos sztereotípiáknak (Herle 2001:22). Lehetne állítani, hogy a Haddon-expedíció ma is példamutató. Ehhez azonban hozzá kell tenni, hogy noha a mai napig fontos a helyiek számára az expedíció által dokumentált információ, sok esetben azt nézik meg, ki mondta, menynyit tudhatott, és joga volt-e elmondani a történetet. Száz évvel később, 19982000 között a Cambridge University Museum kiállítást készített az expedícióról, a találkozásról: az újfajta igények szellemében az együttmúködés jegyében. Emberek, tudások és kapcsolódó tárgyak közötti viszonyokat mutatott be kritikai szemmel. Ebben számos idézet, eredeti szöveg, 300 tárgy és magának az expedíció anyagi kultúrája is jelen volt. A múzeum ily módon terep jellegű helyszínné válhatott ennek révén: különböző ismeretek cseréjének, dialógusok helyeként tudott tovább múködni (Herle 2001:28). 80.

Az ilyen jellegű együttmúködésnek egyik korai példája Franz Boashoz köthető. 1886-ban Johan Adrian Jacobsen és bátyja, Filip nuxalk (Bella Coola, Brit Kolumbia) táncosokat vitt Európába. Boas ebben az időben még Bastiannak dolgozott Berlinben múzeumi asszisztensként. Szabad idejében e meghívott nuxalkokkal azonosíttatta a múzeumi gyưjteményi tárgyakat, közben fotózta e látogatókat, valamint dalaikat jegyezte fel, majd fordíttatta (Miller 2004:181). Ugyanabban az évben először járt náluk terepmunkán, és ennek során a nekik ajándékozott fotók közül sokat már ott talált a házaikban. 
81.

Franz Boas az indián kultúrákat ugyanakkor eleve statikusnak és kihalófélben levőnek tartotta, éppen ezért vált fontossá számára a helyszínen való gyűjtés, ám alapvetően a megmentés szándékával, ez a kutatói attitűd pedig kiszakította a használatból a dolgokat. Boas a kultúrák teljes reprezentációja mellett érvelt, ehhez pedig a sokféle, teljes dokumentációt javasolta; ez eleve több együttmúködést igényelt mindkét fél részéről. 1886 és 1900 között azonban Boas a résztvevő megfigyelésről és a tárgygyưjtésről (azaz arról, amit látott) fokozatosan áttért annak gyưjjtésére, amit hallott: azaz a múltról szóló történetekre (Sanjek ed. 1990:6). E módszertani fordulat részeként tehát a tárgygyüjtésről (ahol is a tárgyak mint ideák szerepeltek; nem a formájuk, hanem a jelentésük volt fontos) a helyi szöve82. gek feljegyzésére, fordítására váltott át.

A korai antropológiai gyưjitésekben a tudományos jellegü leírással párhuzamosan nyert teret a hétköznapi tárgyak gyújtése (a múvészi, egzotikus tárgyakkal szemben), ám ez a nem antropológiai hátterű tárgygyűjtésekre is igaz. Minél fontosabb a leírás, értelmezés, annál nagyobb a hangsúly a résztvevő megfigyelésen. És ugyanez igaz a gyưjiőok jelenlétének idejére: minél több időt töltenek a helyszínen, 83. annál inkább vesznek részt, figyelnek meg.

A gyüjtemények antropológián belüli szerepének háttérbe szorulásával párhuzamosan az anyagi kultúra a strukturalista-funkcionalista, majd szimbolikus antropológiai elméletekben jelentős mértékben kiszorult, láthatatlanná, érdektelenné vált az első vh. után, és ez a fajta vakfolt csak az 1970-es években kezdett fokozatosan visszatérni az antropológiai vizsgálatokba a reprezentáció mint paradigma krízisével párhuzamosan. Ez az a korszak, amikor az antropológián kívül a társadalom-, technológiatudományokon belül, részben a megosztott megismerés, részben a Science and Technology Studies (STS) berkeibe, majd material culture studies keretén belül a tárgyi világ vizsgálata észrevehetően növekedni kezdett, ám valójában egyik sem járt együtt tárgygyüjtéssel.

84.

Az anyagi kultúra vizsgálata - és ezzel párhuzamosan az antropológiai (múzeumi) tárgygyứjtés - visszaszorulásának négy fő oka volt (Harrison 2013:93):

- a funkcionalista antropológiai modell elterjedése

- a résztvevő megfigyelés mint alapvető kutatási mód előtérbe kerülése

- az antropológia áttelepülése az egyetemekre a múzeumok helyett

- a gyarmatok függetlenedése

Valószínúleg azonban finanszírozási gondok is közre játszhattak ebben a folyamatban.

85 .

A tárgyakra összpontosító antropológiai terepmunka a tárgyaknak a társadalmi, kulturális, kognitív és fizikai világban való szerepét igyekszik vizsgálni (lásd Forster 2012:188), ebben a szerepében képvisel sajátos megközelítést az antropológiai vizsgálatokon, terepmunkákon belül. Adódik természetesen a kérdés, hogy $m i$ is az a társadalmi (vagy kulturális, vagy életvilág stb.)? A válasz minden bizonnyal meghatározza a feltett, a feltehető kérdéseket és a válaszokat egyaránt, az eltérő paradigma, elmélet, módszertan hatására,a megfigyelhető és vakfolt jellegű jelenségek szintjén (lásd Forster 2012:54, 186), illetve a tárgyaknak a társadalmin belüli hangsúlyát, jelenlétét illetően. 
86.

„The reduction of objects' life histories to their enrolment in the lives of humans must clearly be questioned (Schiffer 1972, Gosden 2006). Human and material lives are routinely intertwined.

... In these cases, things themselves can come to constitute contexts, which are by no means purely human or social contexts." (Hicks 2010:83) 87.

Tehát az a fajta megközelítési kontextus, melyben a (hétköznapi) tárgyak eleve léteznek és megjelennek egymáshoz képest a helyszínen vagy távolabb, eleve létrehozhat kontextusokat, melyek nem feltétlenül egyszerüsíthetők le társadalmi vagy kulturális hátterekre. 88.

A terepen való megfigyelés lehetővé teszi az aktuális folyamatok, tárgyszerepek múködéséhez, a kapcsolatokhoz, tágabb hálózathoz való közelkerülést. E tárgyak, dolgok történeti vetületeihez és tágabb kapcsolataihoz azonban itt is csak legtöbbször közvetve (például elbeszélés útján) lehet hozzáférni. A terep ebben az esetben ugyanakkor megkönnyítheti mindezt mint megszokott környezet, ám nem teszi közvetlenül hozzáférhetővé, hacsak nem a környezet és a tárgy megtestesülései révén.

89.

A klasszikus antropológia (Malinowski-féle, 1914-1915-es típusú, résztvevő) terepmunka eredménye a szöveg típusú etnográfia, mely a társadalom múködésére összpontosít, célja az ehhez szükséges adatok megszerzése. A terepmunkán alapuló tárgygyüjtés eredménye a tárgygyüjtemény, a megfelelő kontextust leíró ismeretekkel. Ez utóbbiak lehetnek ugyanakkor szintén szövegszerüek, adatbázis jellegűek, képek, filmek. Az így létrejövő tárgygyuujtemények sajátossága viszont a szöveg jellegű dokumentációhoz képest, hogy egymásba épülhetnek, folyamatosan változhatnak, egyre nagyobb, egyre komplexebb gyüjteményt alkotva és ebben a minőségükben állandóan nyitottak maradnak újabb és újabb kérdések számára. 90.

Az antropológiai terepmunka mint közvetlen résztvevő megfigyelés ugyanakkor nemcsak tartalmazhatja adott esetben és célból a tárgyak vizsgálatát, illetve gyưjtését, hanem sok esetben metaforikus kapcsolatba is kerülhet az egyik a másikkal. Gregory Bateson (1958:257) például az etnográfiai terepmunkát, gyüjtést egyenesen a tárgyak gyưjtéséhez hasonlította (Moutu 2007:104). Itt tehát az „etnográfiai anyag” (szövegek, jegyzetek, képek, adatok) összevethető az „etnográfiai tárggyal” (fizikai tárgyakkal). Lévi Strauss (1954) pedig egyenesen azt állította az antropológiai múzeumokról, hogy azok a terep kiterjesztései (mivel a kommunikáció révén rengeteg ember kering bennük; például több, mint tárgy). Ez a metaforikus összekapcsolás újabban nem áll meg a kulturális antropológiánál: Hicks (2013:761), akárcsak Harrison (et al 2013) a múzeumi anyag régészeti metaforáját alkalmazzák, ahol a múzeumi gyüjtemény régészeti leletként és terepként viselkedik, melyet (rétegenként) fel lehet tárni.

91.

Az összekapcsolás alapja minden ilyen esetben maga a gyüjtés; a megfigyelés, a tapasztalat, az adatok, illetve tárgyak, szövegek, ismeretek, képek, emlékek megszerzése, mely egyszerre egyfajta felmérés, mérés, kontroll, rendezés, kiemelés és kihagyás. A gyüjtés tehát nem feltétlenül tárgy jellegü (lásd cenzus, mérés, adat), és nem feltétlenül a gyưjtendő dolgok (adatok, információk) értelmezését akarja elérni, hanem sok esetben megelégszik listák létrehozásával. 
92.

Az antropológiai kutatás során cél a belső perspektívák (émikus leírás) feltárása. Mi a helyzet azonban a tárgygyưjtéssel kapcsolatban? Mi volna az „émikus” a tárgygyưjtésben? És ez hogyan lenne beépíthető a gyüjteménybe? Nemcsak a gyưjjtendő tárgyakkal kapcsolatos értelmezések, információk, adatok kérdése tartozik azonban ide, hanem például: „mit gyưjtenének ők magukról” ? (lásd Moutu 2007 példája is). (Gyakran ennek az ellenkezője müködik a terepen: mitől szabadulnának meg? Illetve hogyan tud belekapcsolódni a gyüjtő a helyi cserébe?) 93

A tárgyak szempontjából a jelentés (fogalmi kontextus) a sürü leírás sajátossága, az ANT jellegú hálózati kontextusa viszont inkább a ritka leírás megfelelője. Mindkettő együttesen adja a tárgy teljesebb kontextusát. A tárgygyüjtemény esetében a kontextus része a teljes tárgyállomány is, annak leírása. A tárgygyưjitemények létrejöttében ráadásul alapvetően fontos a helybeliek (aktív) szerepe mint e kontextus része (lásd Harrison et al eds. 2013). Külön kérdés, hogyan jelentkezik a ritkasűrü leírás megkülönböztetése és használhatósága magában a tárgykutatásban, illetve (még inkább) a (múzeumi) tárgygyưjjtésben?

\section{Tárgygyüjtés és kontextus}

94.

A gyarmatosítás korszakában hamar kialakult egyfajta csere a helyiek és a gyarmatosító gyüjtők között. Ez lehetett rövid vagy hosszú távú kapcsolat, mindegyik sajátos jegyekkel (Torrence - Clarke 2013). A rövid távú kapcsolatokat a helyiek is úgy kezelték, vagyis az értékes, belső, hosszú távú cserekapcsolatokban mozgó tárgyakat nem cseréltek el a gyűjtőkkel ilyen körülmények között. Ehelyett igyekeztek megfelelni a vevők, gyưjtők igényeinek: például díszítették a tárgyakat. Ezekben a cserékben sok a használhatatlan vagy hibrid tárgy. Elkészítésükben és cseréikben részben a helyi csoportok identitását képviselik, részben egy tágabb, regionális identitást a gyarmatosítókkal szemben.

Esetenként azonban máig fennmaradtak olyan helyi értékek (tárgyak) gyưjiteményei is, melyeket a helyiek maguknak őriztek meg (a belső cserékre). Ezek alapján (is) jól látszik viszont, mennyire szelektívek voltak a korai gyüjtések, vagyis mi maradt ki ezekből, és mi az, ami pedig aránytalanul szerepelt. A helyiek tehát jól láthatóan tudatosan vettek részt ezekben a cserekapcsolatokban, alakították ehhez a tárgyaikat, vagy tartottak, vontak ki belőlük másokat. 96.

Fontos észrevenni azt is e tapasztalatok mentén (is), hol válik el a helyi tárgykészlet megfigyelése, tanulmányozása, kutatása éppen a gyưjtéstől. Bár az előbbi esetében is létezik a helyiek valamilyen szintü kontrollja, az utóbbiban ez alapvetően meghatározónak túnik (és legalább ennyire lényeges az értelmezés szempontjából). Itt nem csupán az a kérdés, hogy publikus-e az adott terület (és ennek tárgyai), hanem hogy a helyiek cserébe bocsátják-e azokat. Ha igen, hogyan, milyen feltételekkel? Kialakul-e egyfajta intézménye ennek a cserének, illetve hol vannak a kivételes esetek?

97.

Az egyik tanulság tehát, hogy a terepmunka során nemcsak láthatatlanok maradnak bizonyos dolgok, események, folyamatok, kapcsolatok, mivel a figyelmen kívül esnek (mert eleve ismeretlenek, eleve adottnak tekintjük őket), hanem bizonyos 
dolgok a helyiek révén maradnak ki (például nem lépnek velünk bizonyos fajta viszonyba, cserébe), vagy pedig a (z előbbi) helyi és egyéb (például célok, feltevések, érdeklődés, lehetőségek) körülmények hatására eleve kihagyunk dolgokat a vizsgálatból és még fokozottabban a gyüjtésből. Ezek azonban a kutatás vagy gyüjtés szerves részét, kontextusát alkotják. Tudnunk kell a meglévő anyag értelmezésé98.

hez, hogy mi maradt ki. A teljes gyüjtés mint olyan ugyanis nagyon ritka.

Ma úgy látszik, hogy az ideális múzeumi terepmunkagyüjtés az, amikor a gyűjtött tárgyak a megfelelố antropológiai kutatással és dokumentációval együtt kerülnek a múzeumba. Itt probléma lehet, hogy a múzeumi gyújtésekben óhatatlanul keveredik a gyưjités és a kutatás. Vagyis a tárgykutatás szempontjai (céljai, módszerei stb.) elválhatnak a gyújitéséitốl. Az etnográfiai gyújtések, gyújtemények értéke ugyanakkor a kutatástól függetlenül magas (volt) - éppen a hiány, a megmentés kontextusából kiindulva. Azaz még így is elég értékesek ahhoz, hogy ne mondjon le róla a múzeum.

99.

Az ideális gyűjtés mint olyan azonban számos okból ritka. Ennek ellenére a hozzá tartozó kontextusok (akár részleges) rekonstruálása messze nem lehetetlen vállalkozás (lásd például az új-guineai korai gyarmati cserekapcsolatokat). 100.

A terepkutatás eredménye, mint láttuk, sok esetben az etnográfia: adott jelenségek értelmezése, kontextusba helyezése. A tárgyakkal kapcsolatos leírásokhoz időnként azonban hiányoznak ezek az etnográfiák. A katalóguscédulák, terepjegyzetek önmagukban nem adnak ki egy ilyen jellegü átfogó (holisztikus) kontextust, noha ezek lényegesek az egyes tárgyak helyének, működésének, használatának megértéséhez. (Lásd például Baráthosi Balogh Benedek 20. század eleji jegyzeteit: ezek nagyon fontosak, sok esetben részletesek az egyes tárgyakkal kapcsolatban, a készítésükkel vagy konkrét használatukkal kapcsolatban, de hogy miként éltek az Amur-vidéken, nehéz ezekból rekonstruálni.) 101.

Hasonló módon a múzeumba került tárgy nem feltétlenül fejezi be ezzel a kutatási és terep (mint helyszíni megfigyelés) jellegű pályafutását. A tárgy folyamatosan vagy időról időre újraértelmezhető marad, és a legkülönbözóbb értelmezéseket és leírásokat engedi meg (illetve zár ki másokat). A tárgy lokális értelmezési lehetőségei tehát nem szünnek meg (még generációkkal később sem). Vagyis ebben az értelemben a múzeum mint helyszín terepként értelmezhetố újra. Illetve egy-egy tárgy újabb és újabb szempontú vizsgálata újszerú ismeretekhez vezet(het) a tárgy korábbi használóival, készítőivel, gyújtôiivel, cserélőivel, környezetével kapcsolatban is. 102.

A tárgygyüjtések kezdete óta számos újraértelmezésen, illetve újrarendeződésen mentek keresztül a gyüjitemények: gyưjitôk, kereskedők, misszionáriusok, aukciók, múzeumok, szakértók révén. Lehet persze amellett érvelni, hogy ilyen folyamat, mozgás a kiállítás is; a forrásközösségekkel való, a gyưjteménnyel kapcsolatos múzeumi munkához hasonlóan. Ez utóbbi ugyanakkor egyfajta ásatás, mely szinte a kiállításbeli újrarendezés valódi ellentéte (Byrne 2013:211). Privát, esetleges és kiszámíthatatlan. 


\section{Múzeum mint terep}

103.

A terep a komplexitásával olyan nyitott, gazdag „tárgyként” (társadalmi-fizikaikognitív artefaktumként, illetve ezáltal folyamatként) értelmezhető, mely egy sor kapcsolatot (vizsgálatot és értelmezést) megenged, másokat viszont nem. A terep (és a tárgy) ilyen jellegű komplexitása és nyitottsága tesz tehát lehetővé másképpen (például elbeszélés vagy dokumentáció útján) nehezen vagy hiányosabban megközelíthető vizsgálatokat. Az ilyen jellegű lehetőség egyszerre támogathat, tehet lehetővé kvalitatív és kvantitatív, rövid vagy hosszú idejü megfigyeléseket. Ez a fajta megközelítés folyamatos kapcsolatot keres, igényel a jelenségek és az adatok (megfigyelések) között; illetve elmélet és módszerek között az adatok értelmezése terén (Forster 2012:60). 104 .

A résztvevő megfigyelés, a terep erőssége tehát éppen ez a fajta nyitottság. Ugyanez a nyitottság jellemzi manapság a tárgy újfajta felfogását is. A terep ugyanakkor sürün tagolt aktív, jelen (vagy éppen távol) levő résztvevőkkel (személyekkel, kapcsolatokkal, dolgokkal), a tárgygyüjtemények esetében (éppen a kiemelésük révén) azonban ez a háló ritkább szövésü, vagy csak jóval áttételesebben van jelen. Éppen ez a hasonlóság a tárgy és a terep között azonban egyfajta érv lehet a tárgygyứjtemény, múzeum, archívum mint terep megközelítésére. A másik érv részben összefügg a tárgy és a terep nyitott voltával: mind a „terep”, mind a „gyưjitemény” mint jelenség ugyanis kitágítható (időben és térben egyaránt). Vagyis mindkettő kezelhető úgy is, mint összetett kapcsolatok befejezetlen hálózata. Látható, hogy ez az elmozdulás jellemzi a tárgy, gyüjtemény, illetve a terep kritikai értelmezését is (lásd Gupta - Ferguson 1997). 105.

A terep nyitottsága értelmében tehát használható a múzeumi gyưjteményben való terepmunka fogalma is. Az értelmezések nyitottsága indokolhatja ezt a fajta technikát a megszólaltatásra. Mivel a múzeum (és archívum) vizsgálható nyitott tárgyként, éppen ezért hasonló módon kezelhető terepként is (éppen ebben az értelemben terepen kutatnak a természettudományos kutatók is.) A múzeum (és az archívum) lehet tehát résztvevő megfigyelés helyszíne, ha annyira kitágítjuk e helyszíneket idóben és térben, hogy külső személyeket magukba foglaljanak (Fenske 2007).

106.

A múzeumi gyüjtemény ugyanakkor a konkrétabb, klasszikusabb (azaz szúkebb) értelemben is terepként képes müködni, ha a forrásközösség, illetve az érintett közösségek számára megnyílik, azaz a gyüjteményben való jelenlétük, a gyưjteményhez való viszonyuk az életük részévé képes válni. 107.

A gyüjteményi „nyitottság” ugyanakkor eltér a materiális és a szöveg, vagy kép jellegü dolgok esetében. A terep annyiban valóban nyitott, amennyiben materiális (amibe viszont bizonyos értelemben a társadalmi jelenségek is beletartoznak). Fenske (2007) szemében ugyanakkor az archívum is legalább ennyire terep. Kettős értelemben is az: mint intézmény, és mint életvilágok tára. Ebben a megközelítésben a történeti és a jelenkori kutatás egyaránt és egymáshoz nagyon hasonlóan azzal foglalkozik, amivel találkozik. A kutató szubjektivitása szintén mindkét terepen hat, bár nyilvánvalóan másképpen. 
108.

A tárgy, illetve a gyưjtemény ily módon leginkább folyamatként szemlélhető (nem statikus relációkként), állandó társadalmi kapcsolatokba ágyazódik bele, összekapcsolva a terepet és a múzeumot (Phillips 2005:83), összekötve embereket (helyieket, gyüjtőket, kutatókat, kereskedőket, misszionáriusokat, kiállításlátogatókat) és helyeket, klasszifikációkat, identitásokat, ismereteket téren és időn át. 109.

„... Both objectification and subjectification require work; such processes must be made to happen and maintained. In this sense, things are always events - more or less visible depending on the constant changes in the human and non-human world." (Hicks 2010:84.) 110 .

A múzeumi tárgy és gyüjtemény tehát leginkább folyamataiban és ezáltal létező és alakuló kapcsolataiban ragadható meg, mely folyamatosan oszcillál a jelentés (kategória, fogalom; objektifikáció; modell) és a materiális dolog mint hozzáférés között, és ez az aktorok, dolgok, helyek (múzeum, intézmények, terep; kontaktzóna) és nyelvek (gyuujjtés, kategorizálás, kiállítás, nyelvek, világok) segítségével közelíthető meg.

A múzeumi tárgy ilyen megközelítésben nem kis változáson megy át: ... shift in anthropological thinking about museum objects: »from categorical thinking to relational thinking « (Gosden - Larson 2007:242) (Hicks 2010:62), vagyis a korábbi, eddigi leírások, klasszifikálások mellett a kapcsolatokként való megragadás sem mellőzhető.

A tárgyak folyamat és kapcsolat jellegü vizsgálata (felfogása) párhuzamot talál a nem tárgyi (nem anyagi kultúra jellegü) társadalmi konstrukciók (koordináció, alku mint folyamatok, illetve barátság, segítség, szövetségek...: mint nem materiális artefaktumok, melyek nyomot hagynak a társadalmi környezetben) és a materiális kultúra szerepe, múködése között. Ezáltal jobban pozícionálhatók a tárgyak a társadalmi világon (társadalmi komplexitáson és kogníción) belül (Forster 2012:197).

113.

A terepmunka emellett analógia révén is segíthet a gyưjiteménybe helyezett tárgyak értelmezésében (társadalmi folyamatok értelmezéséhez hasonlóan). Azaz egy tárgy számos folyamat (struktúra, hálózat) része (időbeli, térbeli, analogikus, használat, környezet stb.), és ezek bármelyikének alaposabb feltárása valamilyen tekintetben közelebb visz a tárgy jobb értelmezéséhez.

\section{Együttmúködés a múzeumi terepen} 114 .

Az együttmúködés igénye és szerepe az utóbbi évtizedekben az egész antropológiát átjárja, de ugyanígy megkerülhetetlen a muzeológia terén is. Az antropológiai muzeológia terén ezek a megfontolások nemcsak a kutatásra és értelmezésre, hanem magára a gyüjtésre is összpontosulnak. 115 .

A forrás- és egyéb közösségeknek a múzeumi gyưjiteménybe való bevonása mint igény, mely bizonyos fáziskéséssel, de párhuzamos az általános antropológiai együttmüködési igénnyel, sok hasonlóságot mutat emellett az (az örökséggel valamilyen kapcsolaban álló) örökségközösségek szerepével, ugyanakkor a múzeum 
esetében létezik, adott egyfajta koordinátor funkció (éppen a muzeológus), mely az örökség esetében viszont (egyelőre) hiányzik. A muzeológus ma e közvetítő szerepénél fogva egyben kapuőrző is, éppen azáltal, hogy a múzeumi gyüjteményekhez való hozzáférést koordinálja. 116.

A Néprajzi Múzeumban is mind a magyar, mind a nemzetközi anyag esetében felvetődött az az igény a 20. század során többször, hogy a terepre visszatérve, magukat a gyűjtött a tárgyakat visszavíve „megszólaltassák” azokat (lásd például Györffy István; Fél Edit 1963; Boglár Lajos). Ezekben az esetekben a terep mint a tárgy forráshelyszíne a maga összetettségében (különböző) kontextusokat kínál a tárgy további értelmezéséhez. Emlékeket, hasonló tárgyakat, helyzeteket, történeteket hívnak elő. Bizonyos esetekben e tárgyak mintául szolgál(hat)nak a forrásközösség jelenlegi tagjai számára; új helyzeteket teremthetnek az adott tárgyakkal kapcsolatos ismeretek és társadalmi (vagy tágabb) kapcsolatok újraértékelésében, kiegészítésében, kritikájában, vagy hasonló tárgyak készítéséhez, kereséséhez, használatához, felidézéséhez. Hasonlóan - a tárgy terepen való megszólaltatásához - a forrásközösség tagjait meg lehet hívni, be lehet engedni a gyưjteményekbe, ahol megint csak új helyzetek, reakciók alakulhatnak ki éppen a tárgyak, a gyưjtemény közvetítése (mint határtárgy) révén. Ez a fajta mobil (gyưjteményi) terep olykor képes közvetíteni a múzeum és a forrásközösség között; ugyanakkor a résztvevők köre nem feltétlenül korlátozódik a „forrásközösségekre”, hanem mindazokat szintén összekapcsolhatja hosszabb-rövidebb távon, akiknek bármilyen kapcsolata van vagy volt (vagy lehet) az adott tárgyakhoz (lásd ilyen példákat: Frazon szerk. ...Nyitott Múzeum... 2018 is).

\section{Összegzés}

117.

A terepmunka értelmezhető olyan sajátos és sok helyen alkalmazott kutatási technikaként, mely a kiválasztott helyszín, azaz a terep összetettségére és összefüggéseire alapoz. A terepmunka ennek megfelelően kellően nyitott, ám sosem strukturálatlan. A terep egyszerre a megfigyelés és leírás, a megértés, az összehasonlítás és az értelmezés helyszíne. Ez az írás arra tett kísérletet, hogy ennek az összetett folyamatnak néhány részét kritikai kontextusba helyezze, illetve megpróbálja e keretben elemezni a múzeumi terep fogalmát. 118.

Az elemzés a terep legtágabb értelmezéséből indult, ezt adott összefüggések helyi megfigyelése köti össze. Ebben az értelemben valamennyi empirikus tudomány egyik (eltérő fajsúlyú) adatkereső technikája. A társadalomtudományokon belül ugyanakkor egyre élesebben vetődik fel annak tisztázása, mi is valójában a megfigyelés tárgya. Ez elválaszthatatlan azoktól a kérdésektől, hogy mennyivel és milyen értelemben mások a terepmunka során szerzett ismeretek adott csoportba való szocializáció révén létrejött ismereteknél, milyen háttérhez képest jelennek meg ezek mint új ismeretek. Mint láttuk, e kérdések megválaszolásához jelenleg többféle, egymástól jelentősen eltérő megközelítés létezik. Ezek következetes végiggondolása a terepmunkát radikálisan különbözőképpen rajzolja körbe. Nagyon úgy tűnik, hogy az antropológiai leírás, az etnográfia mibenléte nem hagyja érintetlenül az utóbbi évtizedekben egyre erősebb igényként jelentkező együttmúködés, közös értelmezés esélyeit sem. 
119.

Az is jól látható, hogy mai nézőpontból nincs valódi éles határ az általánosabb antropológiai és a múzeumi antropológiai terep (és ily módon terepmunka) között.

Az, hogy ez alapvetően a jelenleg a korábbinál bátrabban alkalmazott "terep" metaforahasználat eredménye-e vagy a terepmunka mélyebb megértéséből adódik, valószínúleg még nyitott kérdés marad egy darabig. 120.

MIT AD a tárgy a TEREPHEZ?

A társadalmi komplex módon való értelmezését.

A nyitottságot.

A történeti megközelítést (történetiséget).

A határtárgyakat.

\section{MIT AD a gyüjtés a TEREPHEZ?}

A határtárgyat történeti értelemben (lásd kontaktzóna).

A tárgybiográfiai értelmezést.

Az összehasonlítás lehetőségét.

MI INDOKOLJA a tárgygyújtést (a tárgyorientált kutatással szemben vagy amellett)?

A megmentés igénye (lehet kultúra-, tárgyközpontú).

A gyưjjteményképzés.

A materiális vizsgálat igénye (lásd tárgy nyitottsága tárgybiográfia).

Az összehasonlító kutatás.

Önálló dokumentáció.

\section{IRODALOM}

AUSTIN, TERRY - FARNSORTH, JOHN

2005 Hybrid genres: Fieldwork, detection and the method of Bruno Latour. Qualitative Research 5(2):147-165. https://doi.org/10.1177/1468794105048651

BAKOS ÁRON

2018 Enyém, tiéd, miénk? Módszertani javaslat a terepjegyzetek kezelésmódjához. In A néprajzi örökség új kontextusai. Funkció, használat, értelmezés. 231-239. /Kriza Könyvek, 43./

BATESON, GREGORY

1958 Naven. Stanford: Stanford University Press.

BENNETT, TONY

2013 Making culture, changing society. Abingdon: Routledge.

https://doi.org/10.4324/9780203332320

BLOCK, ANDERS

2010 Mapping the super-whale: Towards mobile ethnography of situated globalities. Mobilities 5(4):507-528. https://doi.org/10.1080/17450101.2010.510335 
BREKHUS, WAYNE H. - GALLIHER, JOHN F. - GUBRIUM, JABER F.

2005 The need fot thin description. Qualitative Inquiry 11(6):861-879. http://dx.doi.org/10.1177/1077800405280663

BYRNE, SARAH

2013 Exposing the heart of the museum: the archaeological sensibility in the storeroom. In Reassembling the collection. Ethnographic museums and indigenous agency. Rodney Harrison - Sarah Byrne - Anne Clarke, eds. 199-226. Santa Fe: SAR Press.

CANDEA, MATEI

2019 Comparison in anthropology. The impossible method. Cambridge: Cambridge University Press. https://doi.org/10.1017/9781108667609

\section{CLIFFORD, JAMES}

1988 The predicament of culture: Twentieth century ethnography, literature and art. Cambridge, MA: Harvard University Press.

CLIFFORD, JAMES - MARCUS, GEORGE, EDS.

1986 Writing culture: The poetics and politics of ethnography. Los Angeles: University of California Press.

COLLINS, H. M.

1984 Researching spoonbending: Concepts and practice of participatory fieldwork. In Social researching: Politics, problems, practice. C. Bell - H. Roberts, eds. 54-69. London: Routledge.

CRAPANZANO, VINCENT

1980 Tuhami: Portrait of a Moroccon. Chicago: The University of Chicago Press.

\section{DESCOMBES, VINCENT}

2002 A confusion of tongues. Anthropological Theory 2(4):433-446. https://doi.org/10.1177/14634996020020041101

DUMONT, J-P.

1978 The headman and I: Ambiguity and ambivalence in the fieldworking experience. Austin: University of Texas Press.

DWYER, K.

1982 Moroccon dialogues: Anthropology in question. Baltimore: Johns Hopkins University Press.

\section{ESCOBAR, ARTURO}

1993 The limits of reflexivity: politics in anthropology's post- writing culture era. Journal of Anthropological Research 49:377-391. http://dx.doi.org/10.1086/jar.49.4.3630155

FÉL EDIT

1963 Régi múzeumi tárgyak megszólaltatása új gyüjtésekkel. Néprajzi Értesítő 45:80-90.

FENSKE, MICHAELA

2007 Mikro-, makro-, agency. Történeti néprajz mint kulturális antropológiai praxis. Tabula 10(2):195-219.

\section{FORSTER, DEBORAH}

2012 A state-space approach to social complexity and distributed cognition in olive baboons (Papio anubis): Rethinking the role of behavioral analysis in socio-cognitive research. San Diego: University of California.

FOX, RICHARD, ED.

1991 Recapturing anthropology. Working in the present. Washington: University of Washington Press. 
FRAZON ZSÓFIA, SZERK.

2018 ...Nyitott múzeum... Együttmúködés, részvétel, társadalmi múzeum. Kézikönyv. Budapest: Néprajzi Múzeum.

GEERTZ, CLIFFORD

1973 The interpretation of cultures. New York: Basic Books.

GOSDEN, C.

2006 Material culture and long-term change. In Handbook of Material Culture. C. Tilley et al., eds. London: Sage. 425-441. http://dx.doi.org/10.4135/9781848607972.n28

GUPTA, AKHIL - FERGUSON, JAMES

1997 Discipline and praxis: „The field” as site, method, and location in anthropology. In Anthropological locations. Boundaries and grounds of a field science. Akhil Gupta - James Ferguson, eds. 101-146. Berkeley: University of California Press.

HACKING, IAN

1999 The social construction of what? Cambridge MA: Harvard University Press.

HAHN, HANS-PETER

2005 Dinge des Alltags - Umgang und Bedeutungen. Eine ethnologische Perspektive. In Alltagsdinge. Erkundungen der materiellen Kultur. Gudrun M. König, Hg. Tübingen: Tübinger Vereinigung für Volkskunde. 63-79.

HARRISON, RODNEY - BYRNE, SARAH - CLARCKE, ANNE, EDS.

2013 Reassembling the collection. Ethnographic museums and indigenous agency. Santa Fe: SAR Press.

HAUSWALD, R.

2016 The ontology of interactive kinds. Journal of Social Ontology 2:203-211. https://doi.org/10.1515/jso-2015-0049

HERLE, ANITA

2001 Objects in the active voice: Dialogues between the Torres Strait and Cambridge. Pacific Arts 23-34(7):21-28.

HICKS, DAN

2010 The material-cultural turn: event and effects. In The Oxford Handbook of Material Culture Studies. Dan Hicks - M. C. Beaudry, eds. 25-98. Oxford: Oxford University Press. https://doi.org/10.1093/oxfordhb/9780199218714.013.0002

JACKSON, MICHAEL

2013 Lifeworlds: Essays in existential anthropology. Chicago: Chicago University Press.

\section{KAUFMANN, CHRISTIAN}

2015 Seeing art in objects from the Pacific around 1900: How field collecting and German armchair anthropology met between 1873 and 1910. Journal of Art Historiography 12(6):1-26.

KNEZ, EUGENE I.

1997 Modernization of three Korean villages, 1951-1981: An illustrated study of a people and their material culture. Washington, D. C.: Smithsonian Institution Press.

https://doi.org/10.5479/si.00810223.39.1

LASSITER, LUKE ERIC

2004 Collaborative anthropology. Anthronotes 25(1):1-20. https://doi.org/10.1086/425658

LATOUR, BRUNO

1987 Science in action: How to follow scientists and engineers through society. Harvard: Harvard University Press. 
LATOUR, BRUNO - WOOLGAR, STEVE, EDS.

1986 Laboratory life. The construction of scientific facts. Princeton: Princeton University Press.

LÉVI-STRAUSS, CLAUDE

1954 The mathematics of man. International Social Science Bulletin 6:581-590.

MALIK, SAIRA

2017 Observation versus experiment: An adequate framework for analysing scientific experimentation. Journal for General Philosophy of Science 48:71-95. http://dx.doi.org/10.1007/s10838-016-933.5-y

MARCUS, GEORGE - FISCHER, M. J., EDS.

1986 Anthropology as cultural critique: An experimental moment in the human sciences. Chicago: University of Chicago Press.

MASSIMI, MICHAELA

2015 Working in a new world: Kuhn, constructivism and mind-dependence. Studies in History and Philosophy of Science, Part A, 50:83-89. https://doi.org/10.1016/j.shpsa.2014.09.011

MÉSZÁROS CSABA

2016 Az antropológiai terepmunka perspektívái a rokonság kutatásának tükrében. In Gyújtés és terepmunka a néprajztudományban. Mészáros Csaba - Vargyas Gábor, szerk. Ethno-Lore 33:21-6o.

\section{MILLER, THOMAS ROSS}

2004 Object lessons: Wooden spirits, wax voices, and collecting the folk. In Properties of culture culture as property. Pathways to reform in Post-Soviet Siberia. Erich Kasten, ed. 171-201. Berlin: Dietrich Reimer Verlag.

MORRIS, ROSALIND C.

1994 New worlds from fragments: Film, ethnography, and the representation of Northwest Coast cultures. Boulder: Westview Press.

MOUTU, ANDREW

2007 Collection as a way of being. In Thinking through things. Theorising artefacts ethnographically. Amiria Henare - Martin Holbraad - Saru Wastell, eds. 93-112. London: Routledge.

\section{MUTMAN, MAHMUT}

2006 Writing culture: Postmodernism and ethnography. Anthropological Theory 6(2):153-178. https://doi.org/10.1177/1463499606065033

ORTNER, SHERRY B.

1984 Theory in anthropology since the sixties. Comparative Studies in Society and History 26(1):126-166. https://doi.org/10.1017/So010417500010811

PELS, PETER - NENCEL, LORRAINE

1991 Introduction: Critique and the deconstruction of anthropological authority. In Constructing knowledge: Authority and critique in social science. Lorraine Nencel - Peter Pels, eds. 1-21. London; Newbury Park: Sage Publications.

PHILLIPS, RUTH B.

2005 Re-placing objects: Historical practices for the Second Museum Age. The Canadian Historical Review 86(1):83-110. http://dx.doi.org/10.3138/CHR/86.1.83

RABINOW, PAUL

1977 Reflections on fieldwork in Morocco. Berkeley: University of California Press.

2006 Steps toward an anthropological laboratory. Laboratory for the Anthropology of the Contemporary. Discussion Paper. 
RÓHEIM, GÉZA

1945 The eternal ones of the dream: a psychoanalytic interpretation of Australian myth and ritual. New York: International Universities Press.

RAPPORT, NIGEL - OVERING, JOANNA

2000 Social and cultural anthropology: The key concepts. London: Routledge.

REES, TOBIAS

2007 Concept work and collaboration in the anthropology of the contemporary. ARC Exchange 1: 2-61.

SANJEK, ROGER, ED.

1990 Fieldnotes: The makings of anthropology. Ithaca, NY: Cornell University Press.

SCHIFFER, M. B.

1972 Archaeological context and systematic context. American Antiquity 37(2):156-165.

https://doi.org/10.2307/278203

SCHOLTE, BOB

1969 Toward a reflexive and critical anthropology. In Reinventing anthropology. Del Hymes, ed. 430-457. New York: Pantheon.

1983 Cultural anthropology and the paradigm concept. In The Sociology of the Sciences Yearbook.

L. Graham el al, eds. 229-278. Dordrecht: Reidel.

STÖRING, PASCAL

2018 Data, evidence, and explanatory power. Philosophy of Science 85(3):422-441.

https://doi.org/10.1086/697733

TEDLOCK, BARBARA

1991 From participant observation to the observation of participation: The emergence of narrative ethnography. Journal of Anthropological Research 47:69-94.

https://doi.org/10.1086/jar.47.1.3630581

TEDLOCK, DENIS

1979 The analogical tradition and the emergence of a dialogical anthropology. Journal of Anthropological Research 35:387-400. https://doi.org/10.1086/jar.35.4.36295.37

TORRENCE, ROBIN - CLARKE, ANNE

2013 Creative colonialism: Locating indigenous strategies in ethnographic museum collections. In Reassembling the collection. Ethnographic museums and indigenous agency. Rodney Harrison et al, eds. 171-195. Santa Fe: SAR Press.

TSING, ANNA LOWENHAUPT

2004 Friction. An ethnography of global connection. Princeton - Oxford: Princeton University Press.

TYLER, STEPHEN

1987 The unspeakable: Discourse, dialogue, and rhetoric in the post-modern world. Madison: University of Wisconsin Press.

VENTURA I OLLER, MONTSERRAT

2000 Several representations, internal diversity, one singular people. Social Anthropology 8(1): 61-67. https://doi.org/10.1111/j.1469-8676.2000.tbo0208.x 